NATIONAL LABORATORY

MANAGED BY UT-BATTELLE

FOR THE DEPARTMENT OF ENERGY

\title{
Evaluation of Disposition Options for Mark-18A (Mk-18A) Target Materials
}

May 2013

Prepared by

Sharon Robinson Charles Alexander Jeffery Allender Emory Collins Kenneth Fuller Bradley Loftin Bradley Patton

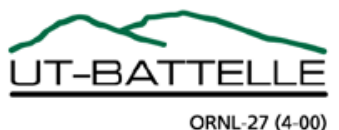




\section{DOCUMENT AVAILABILITY}

Reports produced after January 1, 1996, are generally available free via the U.S. Department of Energy (DOE) Information Bridge.

Web site http://www.osti.gov/bridge

Reports produced before January 1, 1996, may be purchased by members of the public from the following source.

National Technical Information Service

5285 Port Royal Road

Springfield, VA 22161

Telephone 703-605-6000 (1-800-553-6847)

TDD 703-487-4639

Fax 703-605-6900

E-mail info@ntis.gov

Web site http://www.ntis.gov/support/ordernowabout.htm

Reports are available to DOE employees, DOE contractors, Energy Technology Data Exchange (ETDE) representatives, and International Nuclear Information System (INIS) representatives from the following source.

Office of Scientific and Technical Information

P.O. Box 62

Oak Ridge, TN 37831

Telephone 865-576-8401

Fax 865-576-5728

E-mail reports@osti.gov

Web site http://www.osti.gov/contact.html

This report was prepared as an account of work sponsored by an agency of the United States Government. Neither the United States Government nor any agency thereof, nor any of their employees, makes any warranty, express or implied, or assumes any legal liability or responsibility for the accuracy, completeness, or usefulness of any information, apparatus, product, or process disclosed, or represents that its use would not infringe privately owned rights. Reference herein to any specific commercial product, process, or service by trade name, trademark, manufacturer, or otherwise, does not necessarily constitute or imply its endorsement, recommendation, or favoring by the United States Government or any agency thereof. The views and opinions of authors expressed herein do not necessarily state or reflect those of the United States Government or any agency thereof. 
ORNL/TM-2013/148

Nuclear Security and Isotope Technology Division

\title{
EVALUATION OF DISPOSITION OPTIONS FOR MARK-18A (Mk-18A) TARGET MATERIALS
}

\author{
Sharon Robinson \\ Charles Alexander \\ Jeffery Allender* \\ Emory Collins \\ Kenneth Fuller* \\ Bradley Loftin* \\ Bradley Patton
}

*Savannah River National Laboratory

Date Published: May 2013

Prepared by

OAK RIDGE NATIONAL LABORATORY

Oak Ridge, Tennessee 37831-6283

managed by

UT-BATTELLE, LLC

for the

U.S. DEPARTMENT OF ENERGY

under contract DE-AC05-00OR22725 



\section{CONTENTS}

Page

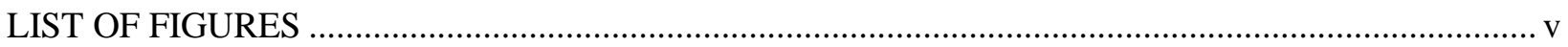

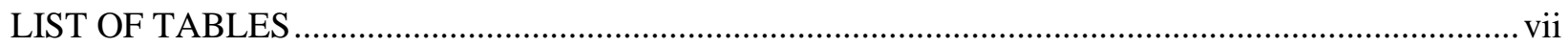

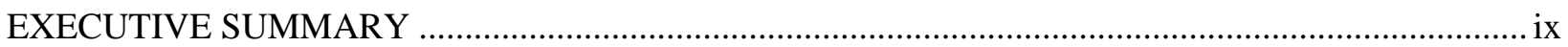

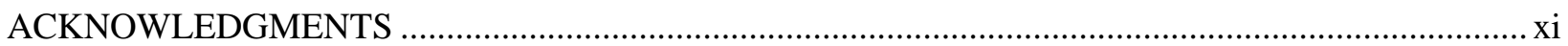

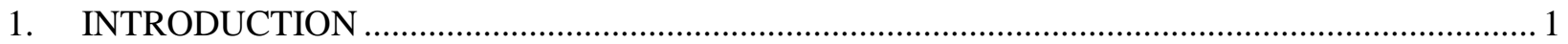

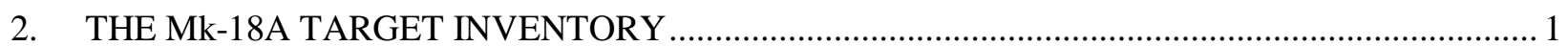

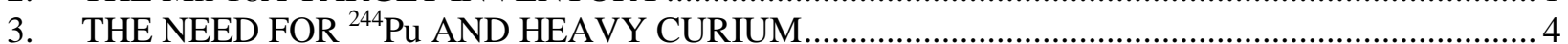

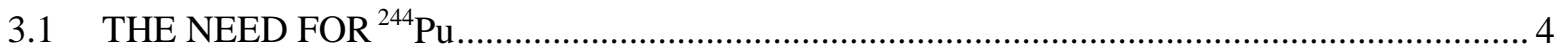

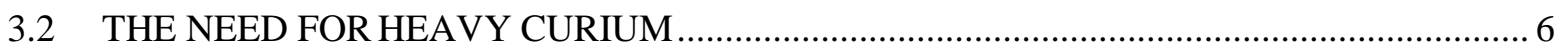

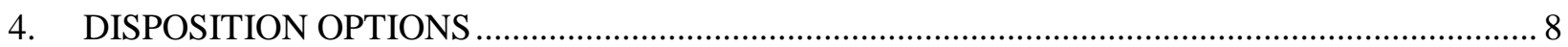

4.1 DISPOSITION PATHWAY 1: REPACKAGING AT SRS AND DISSOLUTION, ${ }^{244} \mathrm{Pu}$ RECOVERY, AND HEAVY-CURIUM RECOVERY AT ORNL ...................................... 9

4.2 DISPOSITION PATHWAY 2: DISSOLUTION OF ALUMINUM CLADDING AT SRS AND ${ }^{244} \mathrm{Pu}$ AND HEAVY-CURIUM RECOVERY AT ORNL ....................................... 9

4.3 DISPOSITION PATHWAY 3: DISSOLUTION AND ${ }^{244} \mathrm{Pu}$ AND HEAVY-CURIUM

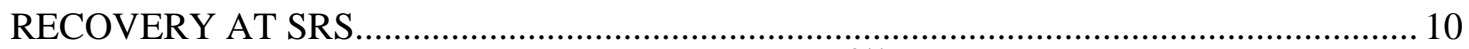

4.4 DISPOSITION PATHWAY 4: DISSOLUTION AND ${ }^{244}$ Pu RECOVERY AT SRS AND CURIUM PROCESSING FOR DISPOSAL AS WASTE AT SRS .............................. 11

4.5 DISPOSITION PATHWAY 5: PROCESSING AT SRS FOR DISPOSAL AS WASTE........ 11

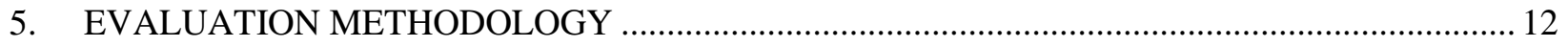

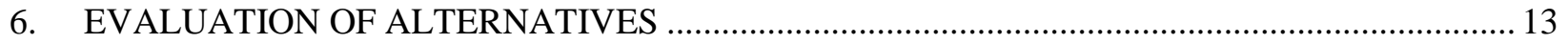

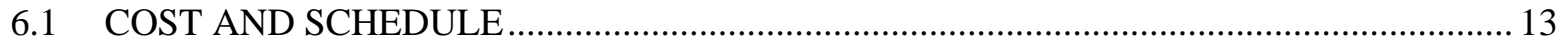

6.2 UNIQUENESS OF THE MATERIAL FOR FUTURE REUSE …...................................... 18

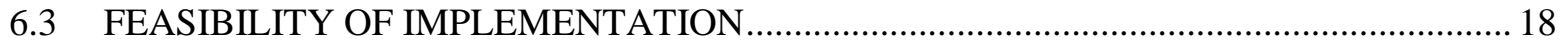

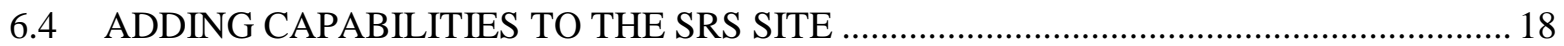

6.5 SUMMARY OF EVALUATED ALTERNATIVES AND RECOMMENDED

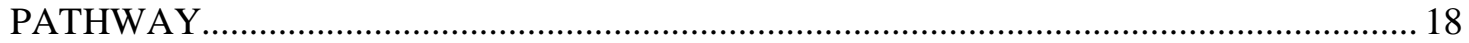

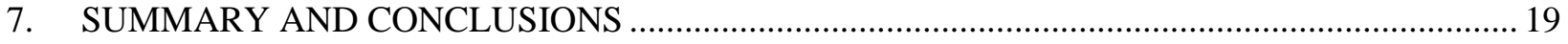

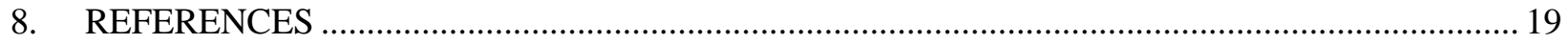

APPENDIX A. EVALUATION CRITERIA DEFINITIONS ............................................................ A-1

APPENDIX B. DETAILED DESCRIPTIONS AND FLOWSHEETS FOR DISPOSITION

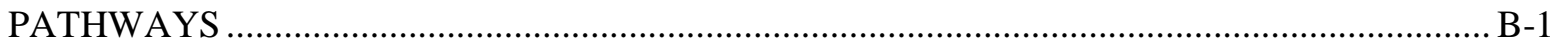

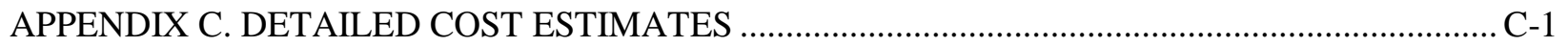





\section{LIST OF FIGURES}

Figure

1 Mk-18A target stored in J-cans in L-Basin at SRS....................................................................... 3

2 Californium-252 production rate as a function of the quality of the curium feedstock....................... 7

3 Disposition of Mk-18A targets via dissolution, plutonium recovery, and heavy-curium

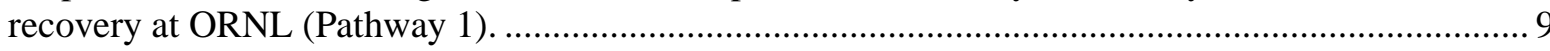

4 Disposition of Mk-18A targets via dissolution of aluminum cladding at SRS and plutonium and heavy-curium recovery at ORNL (Pathway 2) .................................................................... 10

5 Disposition of Mk-18A targets via dissolution and plutonium recovery and heavy-curium recovery at SRS (Pathway 3).

6 Disposition of Mk-18A targets via dissolution, plutonium recovery, and curium processing for

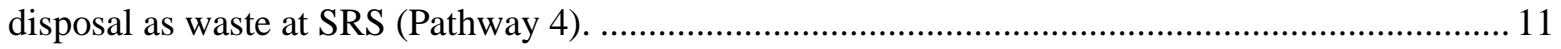

$7 \quad$ Disposition of Mk-18A targets as waste at SRS (Pathway 5)......................................................... 12

8 Preliminary schedule for disposition of Mk-18A targets processing as fast as possible.................... 15

9 Preliminary schedule for disposition of Mk-18A targets processing at a rate needed to support

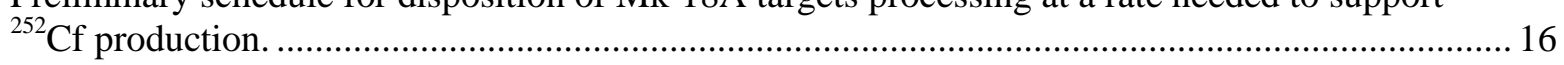

B.1 Disposition of Mk-18A targets via dissolution, plutonium recovery, and heavy-curium

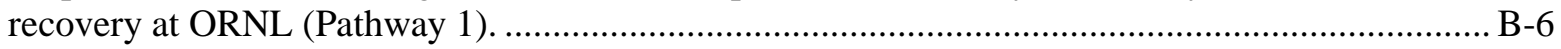

B.2 Disposition of Mk-18A targets via dissolution of aluminum cladding at SRS and plutonium and heavy-curium recovery at ORNL (Pathway 2).

B.3 Disposition of Mk-18A targets via dissolution and plutonium recovery and heavy-curium recovery at SRS (Pathway 3).

B.4 Disposition of Mk-18A targets via dissolution, plutonium recovery, and curium processing for disposal as waste at SRS (Pathway 4).

B.5 Disposition of Mk-18A targets as waste at SRS (Pathway 5)... B-10 



\section{LIST OF TABLES}

Table

Page

1 Estimated Actinide Inventory of Mk-18A Targets (decayed to January 1, 2014) .............................. 2

2 Uses of Isotopes Contained in the Mk-18A Target Materials ........................................................ 5

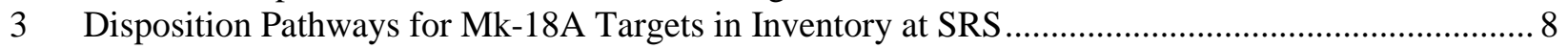

$4 \quad$ Evaluation Results for Mk-18A Disposition Alternatives .......................................................... 13

5 Preliminary Cost Estimate for Mk-18A Disposition Pathways (\$M in 2014 dollars) ....................... 14

6 Preliminary Annual Cost Estimate (in 2014 Dollars) for Disposition of Mk-18A as Fast as

Possible

7 Preliminary Annual Cost Estimate (in 2014 Dollars) for Disposition of Mk-18A at a Rate Needed for ${ }^{252} \mathrm{Cf}$ Production

A.1 Weighting Factors for Evaluation Criteria..................................................................................... A

A.2 Definitions for Rating Alternative Options................................................................................. A-4

C.1 Costs for Disposition of Mk-18A Targets via Dissolution, Plutonium Recovery, and Heavy-Curium Recovery at ORNL (Pathway 1) ........................................................................

C.2 Costs for Disposition of Mk-18A Targets via Dissolution at SRS and Plutonium and Heavy-Curium Recovery at ORNL (Pathway 2) C-4

C.3 Costs for Disposition of Mk-18A Targets via Dissolution and Plutonium Recovery and Heavy-Curium Recovery at SRS (Pathway 3).

C.4 Costs for Disposition of Mk-18A Targets via Dissolution, Plutonium Recovery, and Curium Processing for Disposal as Waste at SRS (Pathway 4).... C-6

C.5 Costs for Disposition of Mk-18A Targets as Waste at SRS (Pathway 5)..... C-7 



\section{EXECUTIVE SUMMARY}

The Department of Energy (DOE) manages an inventory of materials that contains a range of long-lived radioactive isotopes that were produced from the 1960s through the 1980s by irradiating targets in production reactors at the Savannah River Site (SRS). One reactor operated in a high-flux mode to produce special heavy isotopes for defense purposes, DOE programmatic use, scientific research, and industrial and medical applications. Eighty-six Mark-18A (Mk-18A) targets were subjected to long-term high neutron fluences 44 years ago. Twenty-one targets were processed to recover ${ }^{244} \mathrm{Pu}$, heavy curium (i.e., curium rich in ${ }^{246-248} \mathrm{Cm}$ ), and ${ }^{252} \mathrm{Cf}$. The plutonium fraction, which was rich in ${ }^{244} \mathrm{Pu}$, was electromagnetically separated in the Oak Ridge National Laboratory (ORNL) calutrons to produce gram quantities of ${ }^{244} \mathrm{Pu}$. This high-purity sample of ${ }^{244} \mathrm{Pu}$ was portioned out to scientists for basic research and for safeguards programs. The recovered tails (designated as FP-33) contain ${ }^{244} \mathrm{Pu}$ isotopic purities below $20 \%$ and are stored at ORNL. The processing of these $21 \mathrm{Mk}-18 \mathrm{~A}$ targets provided the supply of ${ }^{244} \mathrm{Pu}$ and heavy curium in use today. The 65 unprocessed targets are currently in a storage pool at SRS; they contain the world's supply of unseparated ${ }^{244} \mathrm{Pu}$ and significant amounts of heavy curium needed for heavy-actinide production.

The current inventory of separated ${ }^{244} \mathrm{Pu}$ will be depleted in the near future. In fact, several standards organizations such as New Brunswick Laboratory (NBL) and the Institute for Reference Materials and Measurements (IRMM) have stopped or have severely limited distributing their ${ }^{244} \mathrm{Pu}$ standards in order to conserve the remaining small quantities (at the milligram level) for very high priority needs. The ${ }^{244} \mathrm{Pu}$ in the FP-33 tails stored at ORNL and the unseparated ${ }^{244} \mathrm{Pu}$ in the Mk-18A targets at SRS are the only sources of ${ }^{244} \mathrm{Pu}$ in the world. If these Mk-18A targets are disposed without the separation and recovery of the ${ }^{244} \mathrm{Pu}$, the United States, the International Atomic Energy Agency (IAEA) and other facilities risk losing certain measurement capabilities that are highly essential in maintaining an active nuclear forensics and safeguards posture in current and future world affairs.

In addition, the heavy curium in the Mk-18A targets is needed as long-term feedstock for the production of high-demand heavy actinides such as ${ }^{252} \mathrm{Cf}$ and ${ }^{249} \mathrm{Bk}$. Californium-252 is a radioactive neutron source used in many industrial applications, including oil exploration applications; in process control systems in the cement, coal, and mineral analyzer industries; as sources to start nuclear reactors; in nondestructive materials analyses; and in medical research and health care applications such as cancer treatment. Production of ${ }^{252} \mathrm{Cf}$ at the amounts needed to meet the remaining demand cannot be sustained for more than 14 years without supplementing ORNL's current heavy curium feedstock (curium rich in ${ }^{246-248} \mathrm{Cm}$ ). The most attractive material to supplement the current feedstock is the heavy curium within the Mk-18A targets.

Although the DOE Strategic Plan (US DOE, 2011) has identified the materials in these targets to be rare and economically irreplaceable with defined and potential programmatic uses, the materials presently have no clear sponsor. DOE-Office of Environmental Management (EM) has an option to disposition the targets as waste as part of their SRS cleanup mission if no action is taken.

DOE Office of Nuclear Materials Integration (NA-73) tasked ORNL and Savannah River National Laboratory (SRNL) to evaluate disposition options for the Mk-18A materials. This report summarizes the results of the Mk-18A disposition study.

The study evaluated five options for recovery and/or disposition of the Mk-18A target materials as waste using the SRS H-Canyon to process the material. It concluded that the Mk-18A targets need to be processed through the SRS H-Canyon prior to its shutdown ( 2017 - 2023) to enable the recovery of the 
valuable isotopes at SRS and/or ORNL or disposition the targets as waste. DOE-EM has committed to fund baseline operations of H-Canyon (\$150M/yr) through 2017, and SRS has an inventory of materials to be potentially processed through H-Canyon that could extend the life through $~ 2023$. The time frame for making a decision on the fate of the Mk-18A targets is immediate.

It is recommended that the targets be processed at the SRS H-Canyon prior to its shutdown, and the materials be sent to ORNL for safe storage and subsequent isotopes separations. DOE should also maintain the capability to process the target materials periodically to provide a steady supply of ${ }^{244} \mathrm{Pu}$ and heavy curium. Because of the long lead times to recover the Mk-18A material and to prepare targets and condition the available feed materials, efforts to preserve the irreplaceable ${ }^{244} \mathrm{Pu}$ and replenish the heavycurium feedstock must be initiated immediately to avoid ${ }^{252} \mathrm{Cf}$ supply interruptions. If no effort is made to recover the economically irreplaceable heavy isotopes in these targets, the ${ }^{244} \mathrm{Pu}$ will not only be unavailable to meet existing needs but also for any future potential uses in applied and basic sciences. 


\section{ACKNOWLEDGMENTS}

This worked was funded by the Department of Energy National Nuclear Security Administration NA-73 Office of Nuclear Materials Integration. The work was performed by a team from ORNL and SRNL/SRS. The primary contributors from ORNL were Bradley Patton, Charles Alexander, Porter Bailey, Dale Caquelin, Emory Collins, and Sharon Robinson. The primary contributors from Savannah River were Jeff Allender, Mike Chandler, Mike Dunsmuir, Ken Fuller, and Bradley Loftin. 



\section{INTRODUCTION}

The Department of Energy (DOE) manages an inventory of materials that contains a range of long-lived radioactive isotopes that were produced from the 1960s through the 1980s by irradiating targets in production reactors at the Savannah River Site (SRS). As a by-product of defense materials production, the reactors produced special heavy isotopes for defense purposes, DOE programmatic use, scientific research, and industrial and medical applications (Boswell, 2000). During the late 1960s, the K Reactor was reconfigured to operate in a very high flux mode $\left(6 \times 10^{15} \mathrm{n} / \mathrm{cm}^{2}-\mathrm{s}\right)$. More than 8 kilograms of ${ }^{242} \mathrm{Pu}$, contained in $86 \mathrm{Mk}-18 \mathrm{~A}$ targets, was irradiated to produce large gram-scale amounts of ${ }^{252} \mathrm{Cf}$ for use in a market development program for ${ }^{252} \mathrm{Cf}$ neutron source applications. The driver fuel used $1.2 \mathrm{MT}$ of ${ }^{235} \mathrm{U}$ to irradiate the targets. Twenty-one of the 86 targets were processed in 1972-1973 at ORNL to recover the ${ }^{252} \mathrm{Cf}$ as well as curium rich in the heavy isotopes ${ }^{246} \mathrm{Cm}$ and ${ }^{248} \mathrm{Cm}$. Also, approximately 3 grams of a rare plutonium isotope, ${ }^{244} \mathrm{Pu}$, was recovered and enriched to $98-99 \%$ isotopic purity in the Oak Ridge National Laboratory (ORNL) Actinide Calutron Facility. The processing of these $21 \mathrm{Mk}-18 \mathrm{~A}$ targets is today's source of the world's supply of separated ${ }^{244} \mathrm{Pu}$ and heavy curium. The 65 unprocessed targets are currently in a storage pool at SRS; they contain the world's supply of unseparated ${ }^{244} \mathrm{Pu}$ and significant amounts of heavy curium needed for heavy-actinide production. The reactors and support infrastructure at SRS used to produce the Mk-18A targets have now been shut down.

In 2001, DOE designated the ${ }^{244} \mathrm{Pu}$ in the targets as a National Resource material (Moniz, 2001). The 2011 DOE Strategic Plan (US DOE, 2011) also identified the existing inventory of ${ }^{242 / 244} \mathrm{Pu}$ and ${ }^{244 / 246 / 248} \mathrm{Cm}$ as valuable feedstock for producing new isotopes and categorized them as rare and economically irreplaceable. The Strategic Plan noted the need for DOE to make decisions regarding the preservation of these materials before the opportunity is lost. A recent audit by the Office of the Inspector General (US DOE, 2013) concerning the DOE's management of surplus nuclear materials supports this position. However, the materials have no clear sponsor within DOE at the present time, and the DOE-Office of Environmental Management (EM) may decide to dispose of the targets as waste as part of their SRS cleanup mission.

Therefore, the DOE Office of Nuclear Materials Integration (NA-73) tasked ORNL and Savannah River National Laboratory (SRNL) to evaluate disposition options for the Mk-18A materials. Management of these materials involves processing items for beneficial use and/or for disposition using storage and process facilities at SRS and ORNL. The objective of the study was to identify feasible disposition options, develop preliminary cost estimates for viable options, evaluate each option versus programmatic needs, and recommend dispositioning options for the materials.

This report summarizes the results of the Mk-18A disposition study. The inventory of materials under consideration, their disposition options, preliminary cost estimates, schedules, and a recommended path forward are described below.

\section{THE Mk-18A TARGET INVENTORY}

Eighty-six Mk-18A targets were irradiated in a high-neutron-flux mode in the K-Reactor at SRS from August 1969 until November 1970 and then in a low-flux mode until 1979. The high neutron irradiation resulted in Mk-18A targets with very unique contents.

Upon removal from the reactor, 21 targets were processed at ORNL in $1972-1973$ to recover ${ }^{252} \mathrm{Cf}$, heavy curium, and plutonium. The plutonium fraction, which was rich in ${ }^{244} \mathrm{Pu}$, was electromagnetically separated in the ORNL calutrons to produce gram quantities of $98-99 \%{ }^{244} \mathrm{Pu}$. These high-purity samples 
of ${ }^{244} \mathrm{Pu}$ were portioned out to scientists for basic research and for safeguards programs. The recovered tails (designated as FP-33) contain ${ }^{244} \mathrm{Pu}$ isotopic purities below $20 \%$ and are stored at ORNL. The remaining 65 targets were placed in water basin storage in the SRS Receiving Basin for Offsite Fuels until 2001 when they were moved to their present storage location in L Basin.

The isotopic composition of the Mk-18A targets in storage at SRS is shown in Table 1 . The 21 grams of ${ }^{244} \mathrm{Pu}$ represents the majority ( $>90 \%$ ) of the existing global supply. The Mk-18A targets also contain $\sim 670$ grams of heavy curium, which is $~ 90 \%$ of the nation's heavy-curium inventory. Of particular note is a concentration of more than $80 \%$ of the heavy-curium isotopes $\left({ }^{246} \mathrm{Cm}\right.$ through $\left.{ }^{248} \mathrm{Cm}\right)$. They also contain other valuable high-Z isotopes (e.g., ${ }^{242} \mathrm{Pu},{ }^{243} \mathrm{Am}$ ).

The Mk-18A targets are at risk of deterioration from indefinite long-term underwater storage. Blistering and pitting of the targets were reported when they were withdrawn from the reactor due to the long exposure to high neutron flux, though no leaks or cladding breaches have been observed. The targets have been stored doubly contained in aluminum J-cans in L Basin at SRS since 2001 in their original irradiated form, as shown in Fig. 1. There is concern that the aluminum cladding may have deteriorated and will continue to deteriorate with time, making the targets potentially vulnerable for long-term storage.

Table 1. Estimated Actinide Inventory of Mk-18A Targets (decayed to January 1, 2014)

\begin{tabular}{lc}
\hline Isotope & Mass $(\mathbf{g})$ \\
\hline $\mathrm{Pu}-238$ & 0.2 \\
$\mathrm{Pu}-239$ & 0.06 \\
$\mathrm{Pu}-240$ & 377.7 \\
$\mathrm{Pu}-241$ & 3.5 \\
$\mathrm{Pu}-242$ & 33.5 \\
$\mathrm{Pu}-244$ & 21.4 \\
Total Pu & $\mathbf{4 3 6 . 2}$
\end{tabular}

Am-241

15.7

Am-243

18.5

Total Am

34.2

Cm-244

122.2

Cm-245

9.9

Cm-246

471.1

Cm-247

18.7

Cm-248

44.1

Total Cm

666.0

Total Cf

0.7

Total Actinides

1,137.0 


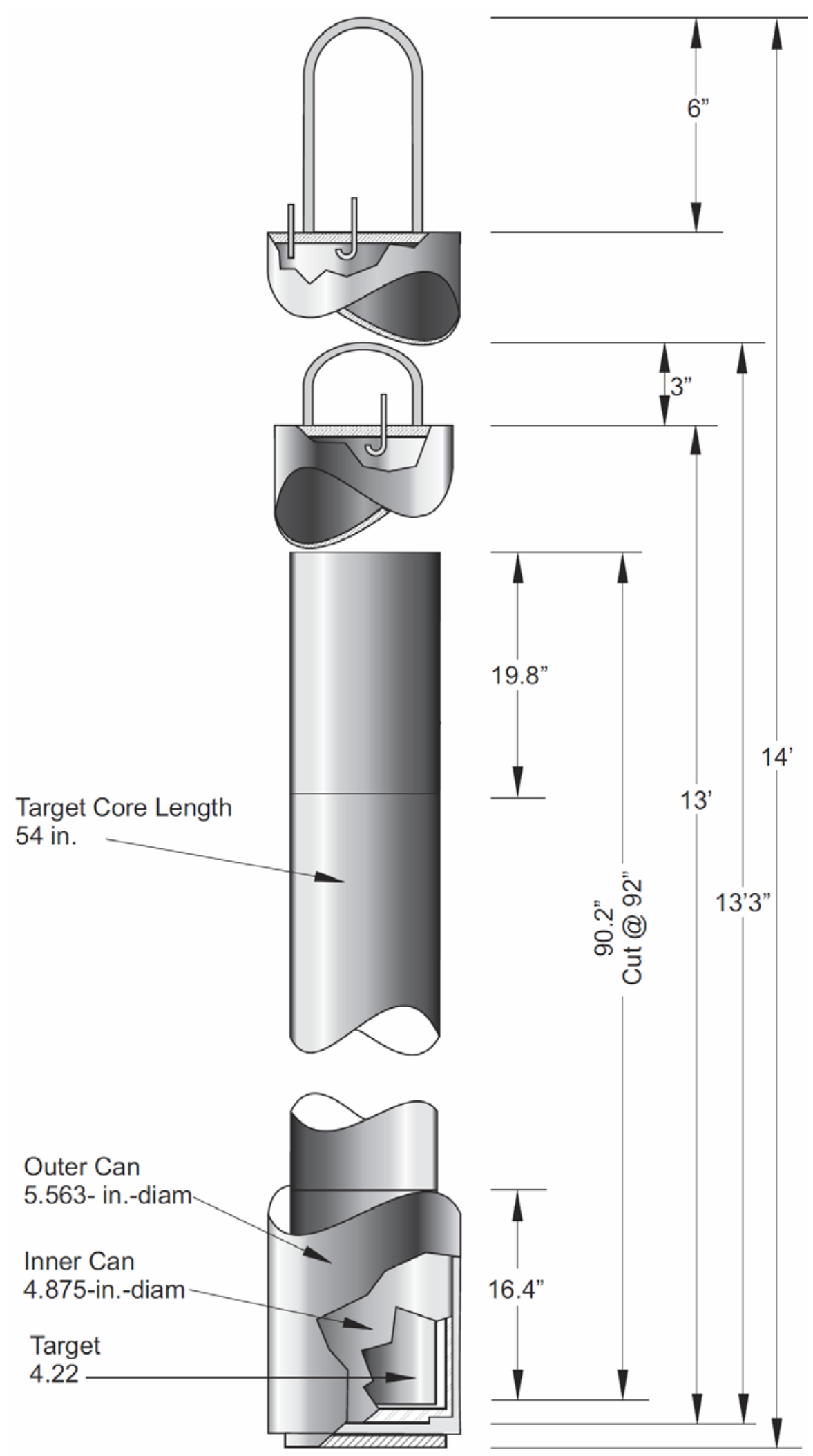

Fig. 1. Mk-18A target stored in J-cans in L-Basin at SRS. 


\section{THE NEED FOR ${ }^{244}$ Pu AND HEAVY CURIUM}

The Mk-18A targets contain approximately $90 \%$ of the world's inventory of ${ }^{244} \mathrm{Pu}$ and heavy curium. Both materials are extremely rare and are economically irreplaceable. Plutonium-244 is a long-lived isotope of plutonium that is not produced in either commercial fuel or weapons-grade plutonium. It provides measurement capabilities that are highly essential in maintaining an active nuclear forensics and safeguards posture in current and future world affairs. The heavy curium is an attractive long-term feedstock for the production of ${ }^{252} \mathrm{Cf}$ and other heavy elements in the High Flux Isotope Reactor (HFIR) at ORNL. The primary applications and users of ${ }^{244} \mathrm{Pu}$ and heavy curium are listed in Table 2 and are summarized below.

\subsection{THE NEED FOR ${ }^{244} \mathrm{Pu}$}

Pure ${ }^{244} \mathrm{Pu}$ is needed at multiple laboratories for use as a reference material for high-precision, destructive analysis techniques such as Isotope Dilution Mass Spectrometry (IDMS). These analytical techniques are needed for supporting R\&D efforts and detecting clandestine activities, as well as for international safeguards efforts due to the expanded use of nuclear fuels for power production. Certified Reference Materials (CRMs) are an essential part of the nuclear materials control and accountability system. Together with analytical procedures, they ensure that the measured amounts of nuclear materials are accurate, comparable, and traceable. There exists a real need to produce nuclear CRMs that meet the needs of the safeguards and nonproliferation communities for ensuring measurements that meet accuracy and precision goals.

The New Brunswick Laboratory (NBL), the domestic supplier of nuclear forensic reference materials, made their ${ }^{244} \mathrm{Pu}$ CRM from the high-purity sample of ${ }^{244} \mathrm{Pu}$ obtained from the processing of the 21 Mk-18A targets in the 1970s. Ten years ago the remaining inventory of their ${ }^{244} \mathrm{Pu}$ was depleted to levels that compelled NBL to stop selling the material due to concerns of limited supply and possible hoarding. A relatively small number of 1-milligram ${ }^{244} \mathrm{Pu}$ units are in stock at NBL but are being held in reserve for critical needs. Many domestic labs, foreign processing facilities, and the IAEA have nearly exhausted their supplies and have inquired about the purchase of several units. As of CY 2013, NBL is making a portion of their stock available on a case-by-case basis.

Small quantities of the recovered tails (designated as FP-33) from processing the original $21 \mathrm{Mk}-18 \mathrm{~A}$ targets are available from ORNL in the form of mixed plutonium isotopes that have ${ }^{244} \mathrm{Pu}$ isotopic purities below $20 \%$. These stocks must be enriched in the ${ }^{244} \mathrm{Pu}$ isotope before they can serve as feed for the certification protocol in the process to becoming CRM for use in forensic analyses. In the 1980s, the IAEA, the United States, and other international laboratories discussed obtaining FP-33 material from the United States to strengthen their safeguards programs. High- ${ }^{244} \mathrm{Pu}$ plutonium that has not been isotopically purified has been evaluated as a potential tracer in fuel-cycle monitoring, but this application is not currently under active development.

Currently, the IAEA has a contract with the DOE to separate ${ }^{244} \mathrm{Pu}$ from 0.5 grams of the FP-33 (17\% ${ }^{244} \mathrm{Pu}$ ) material by using Russian Institute VNIIEF calutrons to $99.99 \%$ purity. The separated material, estimated to be less than a milligram, will be used to create CRM at NBL and will be provided to the IAEA to distribute to international laboratories for use in nuclear safeguards forensic activities. 
Table 2. Uses of Isotopes Contained in the Mk-18A Target Materials

\begin{tabular}{|c|c|c|c|c|c|c|}
\hline & $\begin{array}{l}\text { Isotopes of } \\
\text { Interest }\end{array}$ & Uses & $\begin{array}{l}\text { Potential } \\
\text { Sponsor }\end{array}$ & $\begin{array}{l}\text { Sponsor's } \\
\text { Sponsor }\end{array}$ & Stake Holder & Applications \\
\hline & $\begin{array}{l}\text { Heavy Curium - } \\
{ }_{246-248} \mathrm{Cm}\end{array}$ & $\begin{array}{l}\text { Feedstock for } \\
{ }^{252} \mathrm{Cf} \text { Production } \\
\text { (Provide high- } \\
\text { yield feedstock } \\
\text { to last through } \\
\text { lifetime of HFIR) }\end{array}$ & DOE-SC (NP) & $\begin{array}{l}\text { - }{ }^{252} \text { Cf Consortium } \\
\text { - Frontier Technology } \\
\text { - QSA Global } \\
\text { - B\&W } \\
\text { - GE-Hitachi } \\
\text { - Eckert \& Zieglev } \\
\text { - R\&D Community }\end{array}$ & $\begin{array}{l}\text { - Nuclear Reactor } \\
\text { Operations } \\
\text { - DOE } \\
\text { - U.S. Navy } \\
\text { - Commercial } \\
\text { Nuclear Power } \\
\text { - Oil Exploration } \\
\text { Industry } \\
\text { - Medical R\&D } \\
\text { - DOE Laboratories } \\
\text { - Foreign Laboratories }\end{array}$ & $\begin{array}{l}\text { - Oil Well Logging (OWL) } \\
\text { - Thickness Gauging } \\
\text { - Reactor Startup } \\
\text { - } \text { Fuel Rod Scanning } \\
\text { - Materials Neutron Analysis } \\
\text { - } \text { Medical R\&D } \\
\text { - Education } \\
\text { - Equipment Calibration, } \\
\text { - Testing } \\
\text { - Radiation Instrument } \\
\text { Calibration }\end{array}$ \\
\hline $\begin{array}{l}\text { Mk-18A } \\
\text { Targets }\end{array}$ & $\begin{array}{l}\text { Plutonium High } \\
\text { in }{ }^{244} \mathrm{Pu}\end{array}$ & $\begin{array}{l}\text { Feedstock for } \\
\text { Producing }{ }^{244} \mathrm{Pu} \\
\text { Standards/ } \\
\text { Special R\&D } \\
\text { Projects }\end{array}$ & $\begin{array}{l}\text { NA-20 } \\
\text { IAEA }\end{array}$ & $\begin{array}{l}\text { - DHS DNDO } \\
\text { - Department of } \\
\text { Defense } \\
\text { - Defense Threat } \\
\text { ReductionAgency } \\
\text { (DTRA) } \\
\text { - IAEA }\end{array}$ & $\begin{array}{l}\text { - Any Organization } \\
\text { Conducting High } \\
\text { Precision Pu Isotopic } \\
\text { Determination } \\
\text { - IAEA } \\
\text { - Universities } \\
\text { - New Brunswick } \\
\text { Laboratory } \\
\text { - MOX Plant } \\
\text { - Pu Processing } \\
\text { Facilities Worldwide } \\
\text { - Institute for } \\
\text { Reference Materials } \\
\text { and Measurements } \\
\text { (IRMM) } \\
\text { - Environmental Pu } \\
\text { Transport R\&D }\end{array}$ & $\begin{array}{l}\text { - Certified Reference } \\
\text { Material (CRM) } \\
\text { - Spike for High Precision } \\
\text { Pu Isotopic Determinations } \\
\text { - Target for Super Heavy } \\
\text { Element R\&D } \\
\text { - Low Activity Pu for Basic } \\
\text { Pu R\&D }\end{array}$ \\
\hline
\end{tabular}


Scientists at the DOE laboratories, National Institute of Standards and Technology (NIST), the IAEA, European Atomic Energy Community (EURATOM) and other international laboratories are concerned with the limited availability of separated ${ }^{244} \mathrm{Pu}$ and clearly see a need for recovering more ${ }^{244} \mathrm{Pu}$ and other pure isotopes to perform highly precise measurements of plutonium (Goldberg, 2001). No other isotopic material can perform the unique function of ${ }^{244} \mathrm{Pu}$ in high-accuracy measurements of plutonium for both safeguards and environmental analyses. Typical high-precision plutonium measurements at these laboratories are performed with isotope dilution mass spectrometry (IDMS) using a "spike" of 1-5 micrograms of ${ }^{244} \mathrm{Pu}$ per gram of total plutonium. Without this spike of the (otherwise absent) isotope, analyses require extended time and cost to calibrate equipment and achieve adequate characterization.

Because of the limited supply of high-purity ${ }^{244} \mathrm{Pu}$ needed for CRM, many scientists have begun to use ${ }^{242} \mathrm{Pu}$ for certain applications. However, ${ }^{242} \mathrm{Pu}$ is not as suitable for detecting fugitive plutonium releases in environmental samples and to establish the provenance of such releases. Therefore, interest in low-level environmental reference materials for safeguards applications has greatly increased the need for ${ }^{244} \mathrm{Pu}$ since it improves the precision and accuracy of isotopic measurements in the field. Other tracers can be used (such as ${ }^{242} \mathrm{Pu}$ ) but will not yield the same quality results in terms of measurement sensitivity as the ${ }^{244} \mathrm{Pu}$. The limited stock of high-purity ${ }^{244} \mathrm{Pu}$ obtained from processing of the original $21 \mathrm{Mk}$-18A targets and the materials to be produced under the IAEA contract will not meet projected CRM demands for highly enriched ${ }^{244} \mathrm{Pu}$.

The ${ }^{244} \mathrm{Pu}$ material has also been used and is needed as target materials for heavy-ion bombardment for studies of transactinide elements. These isotopes are used in the production and discovery of the superheavy elements. As an example, in December 1998, a team of scientists from Lawrence Livermore National Laboratory and the Joint Institute for Nuclear Research in Dubna, Russia, discovered element 114 (Flerovium) using a heavy-ion cyclotron to bombard a film of ${ }^{244} \mathrm{Pu}$ with ${ }^{48} \mathrm{Ca}$ ions for 40 days (an achievement which was recognized by Popular Science as one of the year's 100 greatest achievements in science and technology).

In addition, the ${ }^{244} \mathrm{Pu}$ isotope has a half-life that is over 200 times longer than any other plutonium isotope, making it extremely useful in any studies that attempt to pin down the thermodynamics of plutonium in either solution or solid state. Plutonium-244 is also the prime isotope for plutonium ultratracing as well. As the world continues to run nuclear power plants and recycle fuels, the ${ }^{242} \mathrm{Pu}$ fraction in the environment will increase, rendering that isotope unsuitable as a plutonium tracer. However, ${ }^{244} \mathrm{Pu}$ is not produced in appreciable quantities in standard power reactor fuel and will not build up in the environment; making it uniquely valuable as a tracer for plutonium.

\subsection{THE NEED FOR HEAVY CURIUM}

The heavy curium in the Mk-18A targets is an optimal feedstock for ${ }^{252} \mathrm{Cf}$ production. Californium-252 is a radioactive neutron source used in many industrial applications including oil exploration applications; process control systems for analyzers in the cement, coal, and mineral analyzer industries; sources to start nuclear reactors; nondestructive materials analyses; and medical research and health care applications such as cancer treatment.

The production of ${ }^{252} \mathrm{Cf}$ requires both a high-flux reactor and a unique feedstock. Since ${ }^{252} \mathrm{Cf}$ has a short half-life (2.6 years), it decays at a rate of about $25 \%$ per year, and new supplies need to be manufactured regularly to meet the various user communities' needs. In the process of producing ${ }^{252} \mathrm{Cf}$, other heavy actinides are produced as by-products. These include ${ }^{249} \mathrm{Bk},{ }^{254} \mathrm{Es}$, and ${ }^{255} \mathrm{Fm}$. In $2009-2010,{ }^{249} \mathrm{Bk}$ was recovered at ORNL's Radiochemical Engineering Development Center (REDC) and used in a multinational collaborative discovery of element 117 . Additional ${ }^{249} \mathrm{Bk}$ is being used to confirm the discovery of element 117 and perhaps the discovery of element 119 . Californium-251 from decayed ${ }^{252} \mathrm{Cf}$ 
sources is also being harvested at the REDC for use in the discovery of superheavy elements (elements 117, 119, and beyond).

The heavy curium in the Mk-18A targets is an optimal feedstock for ${ }^{252} \mathrm{Cf}$ production, as shown in Fig. 2. Currently, the ${ }^{252} \mathrm{Cf}$ production program is relying on the existing supply of heavy curium (derived from earlier processing of the Mk-18A targets) as a feedstock for the production of ${ }^{252} \mathrm{Cf}$. As the existing supply of heavy curium is depleted, new sources of curium will be needed to efficiently and effectively produce ${ }^{252} \mathrm{Cf}$ in the ORNL HFIR. Production of ${ }^{252} \mathrm{Cf}$ at the amounts needed to meet the current demand cannot be sustained beyond $\sim 2025$ without supplementing the ORNL current heavy-curium feedstock (curium rich in ${ }^{246-248} \mathrm{Cm}$ ). The Mk-18A targets contain $\sim 670$ grams of heavy curium that is optimal for ${ }^{252} \mathrm{Cf}$ production. Other much less attractive material options for supplementing the current feedstock include the existing light-curium material in inventory at ORNL (shown as CmII and Mk42 Avg. in Fig. 2) and the ${ }^{242} \mathrm{Pu}$ currently in inventory in the DOE complex. The elemental and isotopic composition of the feedstock has a significant impact on the production of the ${ }^{252} \mathrm{Cf}$. The lighter the feedstock, the more neutron captures are required for the production of ${ }^{252} \mathrm{Cf}$, which requires significantly more irradiation time in the HFIR and incurs more fission losses and higher costs. Lighter curium requires the fabrication of more targets, and it costs more to irradiate the targets in the HFIR to produce the same amount of ${ }^{252} \mathrm{Cf}$ compared to using heavy curium as the feedstock.

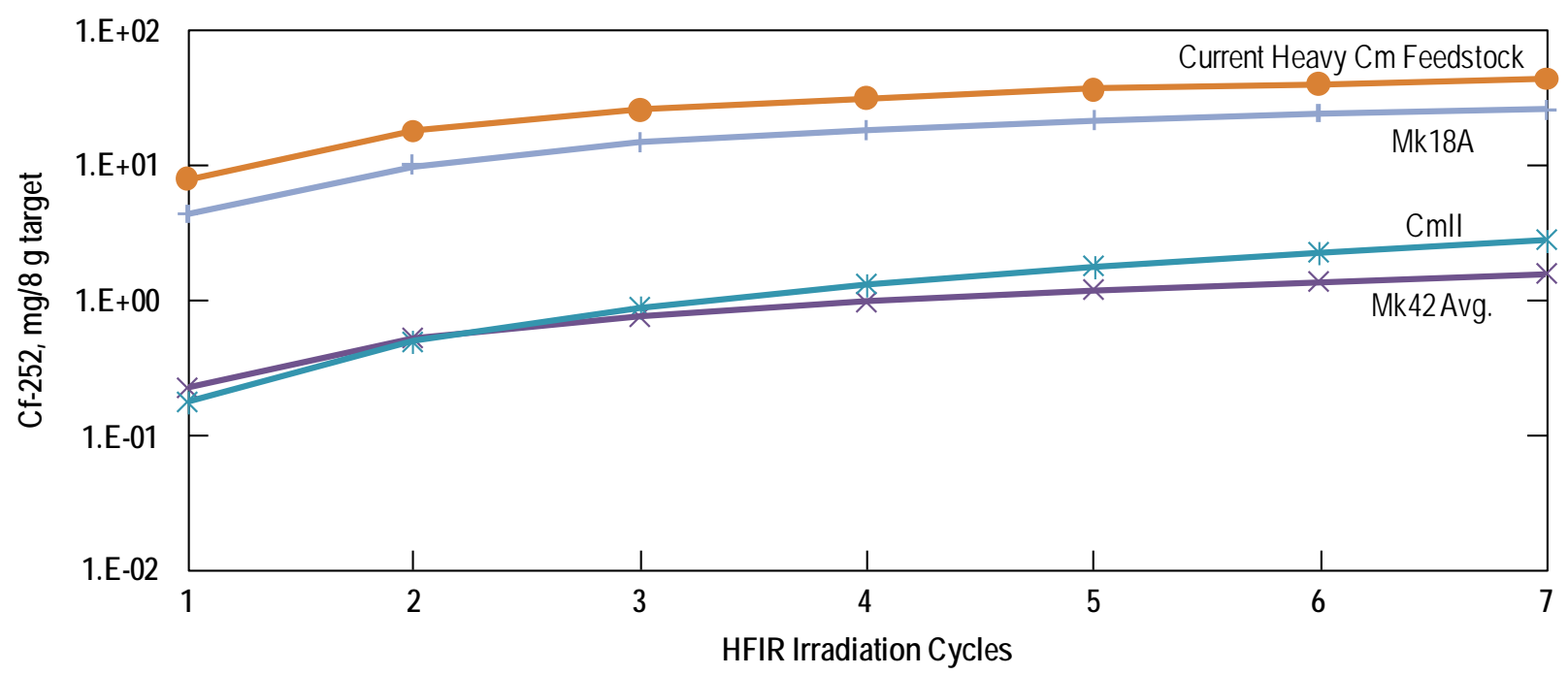

Fig. 2. Californium-252 production rate as a function of the quality of the curium feedstock.

The present plan for producing ${ }^{252} \mathrm{Cf}$ includes using light curium in the ORNL inventory to make up for the shortage of heavy curium. However, it may be more economical to recover heavy curium from the Mk-18A targets than to use existing inventories of light curium for ${ }^{252} \mathrm{Cf}$ production. Initial estimates indicate that use of the heavy curium in the Mk18A targets would reduce the number of required targets by $50 \%$ and the irradiation period could also be reduced by $50 \%$. This could reduce the costs of ${ }^{252} \mathrm{Cf}$ production by $\sim \$ 70 \mathrm{M}$ for the period of $20+$ years.

In addition, the light curium does not represent a long-term supply of ${ }^{252} \mathrm{Cf}$ feedstock. Heavy curium in the Mk-18A targets would provide high-yield ${ }^{252} \mathrm{Cf}$ feedstock for the $20+$ years. 


\section{DISPOSITION OPTIONS}

Potential disposition options to be evaluated include

- $\quad$ recovery of ${ }^{244} \mathrm{Pu}$ and heavy curium for future use,

- recovery of ${ }^{244} \mathrm{Pu}$ only for future use and processing of the heavy curium for disposal at a geological repository, and

- $\quad$ processing the targets for disposal as waste at a geological repository without recovery of ${ }^{244} \mathrm{Pu}$ or heavy curium.

The major steps in the disposition pathways include packaging/transport of the targets to treatment/storage/disposal facilities, dissolution of the targets, and processing of the material for recovery of isotopes and/or disposal as waste. For this report, recovery is defined as separation into plutonium and heavy curium/americium/lanthanides oxide streams for storage for future use.

Inclusion of processing locations led to the development of five potential pathways for disposition of the Mk-18A targets, as summarized in Table 3. SRS facilities are considered the only viable location for processing materials for disposition as waste. Both the SRS and ORNL sites were considered for the ${ }^{244} \mathrm{Pu}$ and heavy-curium-recovery processing steps. All SRS processing operations were assumed to occur in H-Canyon.

Table 3. Disposition Pathways for Mk-18A Targets in Inventory at SRS

\begin{tabular}{lcccc}
\hline \multicolumn{1}{c}{ Pathway } & $\begin{array}{c}\text { Target } \\
\text { Dissolution }\end{array}$ & $\begin{array}{c}{ }^{244} \text { Pu } \\
\text { Recovery }\end{array}$ & $\begin{array}{c}\text { Heavy-Cm } \\
\text { Recovery }\end{array}$ & $\begin{array}{c}\text { Processing for Disposal } \\
\text { as Waste }\end{array}$ \\
\hline $1-\mathrm{Pu} / \mathrm{Am} / \mathrm{Cm}$ recovered at ORNL & ORNL & ORNL & ORNL & NA \\
$2-\mathrm{Pu} / \mathrm{Am} / \mathrm{Cm}$ recovered at & SRS & ORNL & ORNL & NA \\
SRS/ORNL & & & & NA \\
$3-\mathrm{Pu} / \mathrm{Am} / \mathrm{Cm}$ recovered at SRS & SRS & SRS & SRS & SRS (Heavy Cm only) \\
$4-\mathrm{Pu}$ recovered at SRS & SRS & SRS & NA & SRS (All) \\
$5-$ No recovery & SRS & NA & NA & \\
\hline
\end{tabular}

In scenarios where the isotopes are recovered for future use, the disposition endpoint is storage as oxides in sealed capsules at ORNL's REDC. The ${ }^{244} \mathrm{Pu}$ would be recovered from the Mk-18A targets, converted to an oxide, and stored in sealed capsules awaiting future enrichment. The heavy curium/americium/lanthanides would be converted to oxides and stored in sealed capsules for future heavy-actinide production by irradiation in HFIR. The disposition endpoint for Mk-18A targets considered for disposal as waste is interim storage of a solidified waste form at SRS followed by ultimate disposition at a geological repository when it becomes available for DOE-owned irradiated fuel and target and high-level waste. Long-term storage at another location at the SRS is not considered an attractive option because of concerns associated with deterioration of the aluminum cladding. In addition, the option does not represent an acceptable endpoint, and no long-term storage sites are available at the SRS. The processing pathways for disposition are described as follows, and detailed descriptions are given in the appendices. 


\subsection{DISPOSITION PATHWAY 1: REPACKAGING AT SRS AND DISSOLUTION, ${ }^{244} \mathrm{Pu}$ RECOVERY, AND HEAVY-CURIUM RECOVERY AT ORNL}

In this scenario, the Mk-18A targets would be shipped from SRS to ORNL, where they would be processed at the ORNL REDC to recover the heavy curium for future use in the production of heavy actinides $\left({ }^{252} \mathrm{Cf}\right.$, ${ }^{249} \mathrm{Bk}$, etc.) and to recover the plutonium for future enrichment. Figure 3 provides the proposed process flow diagram for Disposition Pathway 1. The targets would be retrieved from their storage location in L-Basin at SRS, repackaged for off-site transport, and shipped to ORNL. The physical properties of the targets stored in J-cans are presently unknown. It is assumed that they may have become embrittled to the point that they may need to be transferred to an isolation system for repackaging for off-site shipment. Long reactor exposures of the aluminum will have converted a fraction of the cladding to silicon.

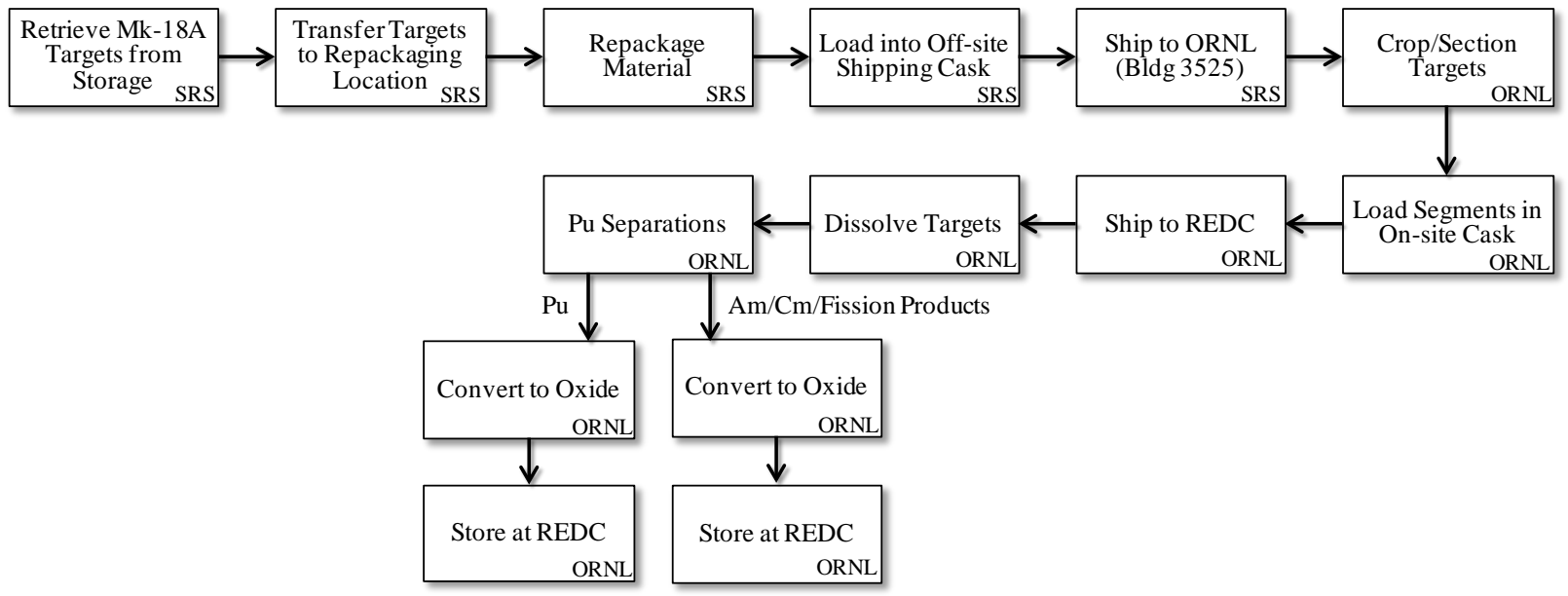

Fig. 3. Disposition of Mk-18A targets via dissolution, plutonium recovery, and heavy-curium recovery at ORNL (Pathway 1).

The targets would be shipped to ORNL's Irradiated Fuels Examination Laboratory (IFEL) in Bldg. 3525, where they would be cropped and sectioned into sizes that can be stored/processed in existing facilities at REDC. The segments would then be shipped to REDC, where they would be stored prior to being dissolved and the plutonium isotopes rich in ${ }^{244} \mathrm{Pu}$ separated from the Am/Cm/fission products. The plutonium would be converted to an oxide, put into storage cans, and placed in storage at REDC for future enrichment of the ${ }^{244} \mathrm{Pu}$. The Am/Cm/fission products stream would be converted to an oxide, put into storage cans, and placed in storage for future use in targets for irradiation at HFIR.

\subsection{DISPOSITION PATHWAY 2: DISSOLUTION OF ALUMINUM CLADDING AT SRS AND ${ }^{244}$ Pu AND HEAVY-CURIUM RECOVERY AT ORNL}

Disposition Pathway 2 is similar to Pathway 1 except the Mk-18A targets' aluminum cladding and matrix would be dissolved in caustic at SRS. The remaining insoluble actinide materials would be processed into a solid $\mathrm{Pu} / \mathrm{Am} / \mathrm{Cm} /$ fission products mixture prior to shipment to ORNL for recovery of the plutonium and heavy curium. The steps in Disposition Pathway 1 to remove the J-cans to permit off-site shipment of the targets from SRS and the cropping/sectioning step at ORNL would be replaced with chemical processing steps at SRS to dissolve the aluminum cladding/matrix, recover the undissolved $\mathrm{Pu} / \mathrm{Am} / \mathrm{Cm} / \mathrm{fission}$ products stream, and stabilize the material for shipment to ORNL.

Figure 4 provides the proposed process flow diagram for Pathway 2. The targets would be retrieved from their storage location in L-Basin at SRS and shipped to H-Canyon where the aluminum cladding/matrix 
and caustic soluble fission products, including the ${ }^{137} \mathrm{Cs}$, would be dissolved in caustic and disposed of as waste. The $\mathrm{Pu} / \mathrm{Am} / \mathrm{Cm} /$ caustic-insoluble fission products oxides would be dried, stabilized, and packaged in containers that would be shipped to ORNL. The packaged material would be unloaded from the off-site shipping container and transferred to an on-site shipping cask in ORNL's IFEL. The Mk-18A material would then be shipped to REDC, where it would be stored until it could be dissolved in nitric acid and the plutonium separated from the Am/Cm/fission products. The plutonium-bearing stream would be converted to an oxide, put into storage cans, and placed in storage at REDC for future enrichment. The

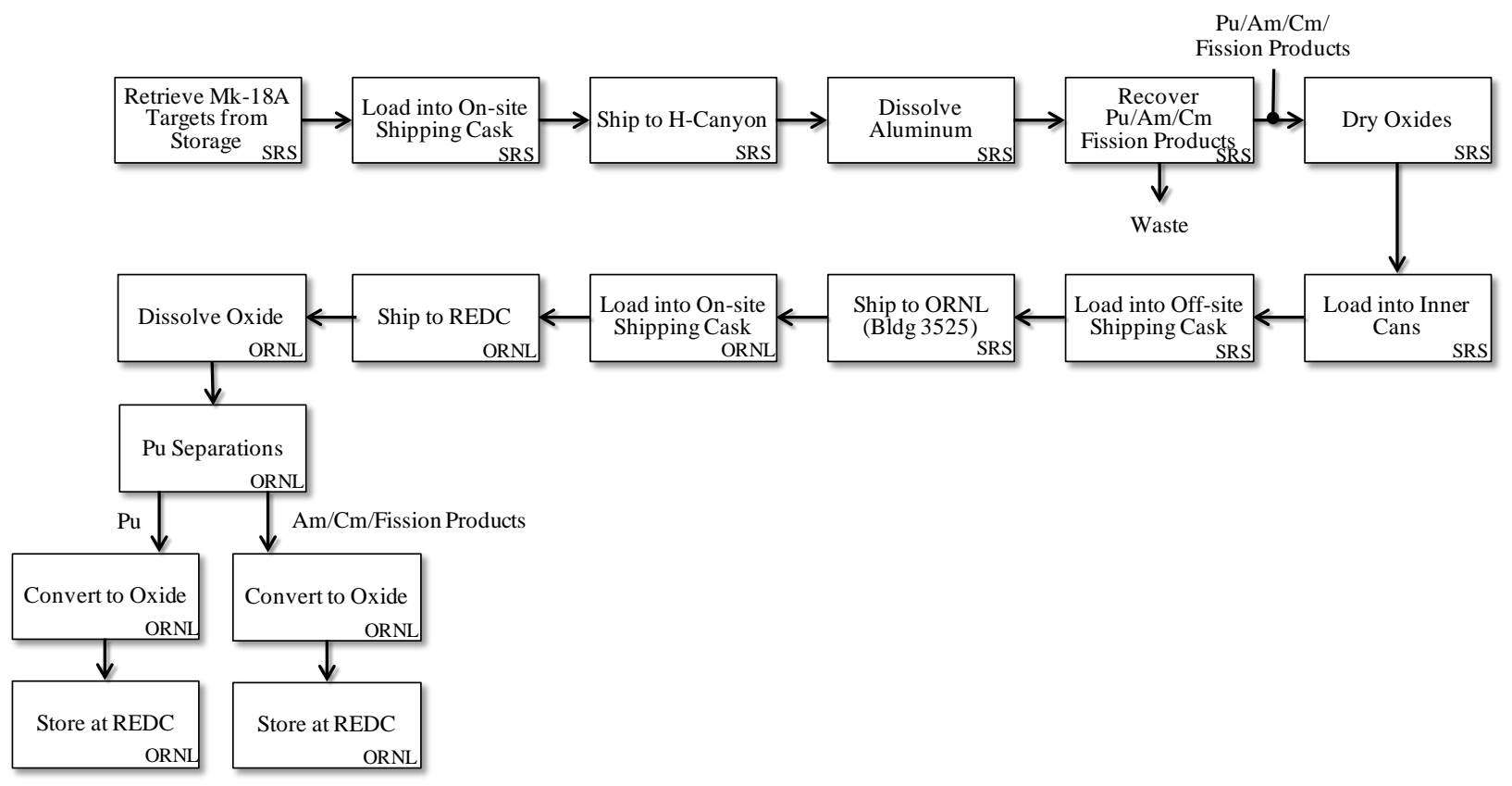

Fig. 4. Disposition of Mk-18A targets via dissolution of aluminum cladding at SRS and plutonium and heavy-curium recovery at ORNL (Pathway 2).

Am/Cm/fission products solution would be converted to an oxide, put it into storage cans, and placed in storage at REDC for future use.

\subsection{DISPOSITION PATHWAY 3: DISSOLUTION AND ${ }^{244}$ Pu AND HEAVY-CURIUM RECOVERY AT SRS}

Disposition Pathway 3 is same as Pathway 2 except the entire target material would be dissolved in nitric acid and the actinide recovery steps would be performed at SRS rather than ORNL. Two streams from the plutonium separations step (a ${ }^{244} \mathrm{Pu}$-rich stream and the Am/Cm/fission products stream) would be processed into separate oxide streams prior to shipment to ORNL for storage.

Figure 5 provides the proposed process flow diagram for Pathway 3. The targets would be retrieved from their storage location in L-Basin at SRS and shipped to H-Canyon where they would be dissolved and the plutonium separations step would be performed. The ${ }^{244} \mathrm{Pu}$-rich stream and the Am/Cm/fission products stream from the plutonium separations step would each be converted to oxides and packaged as two separate streams in containers that could be shipped to ORNL. The materials would be transferred from the off-site shipping container to an on-site shipping cask in IFEL prior to being shipped to REDC for storage. 


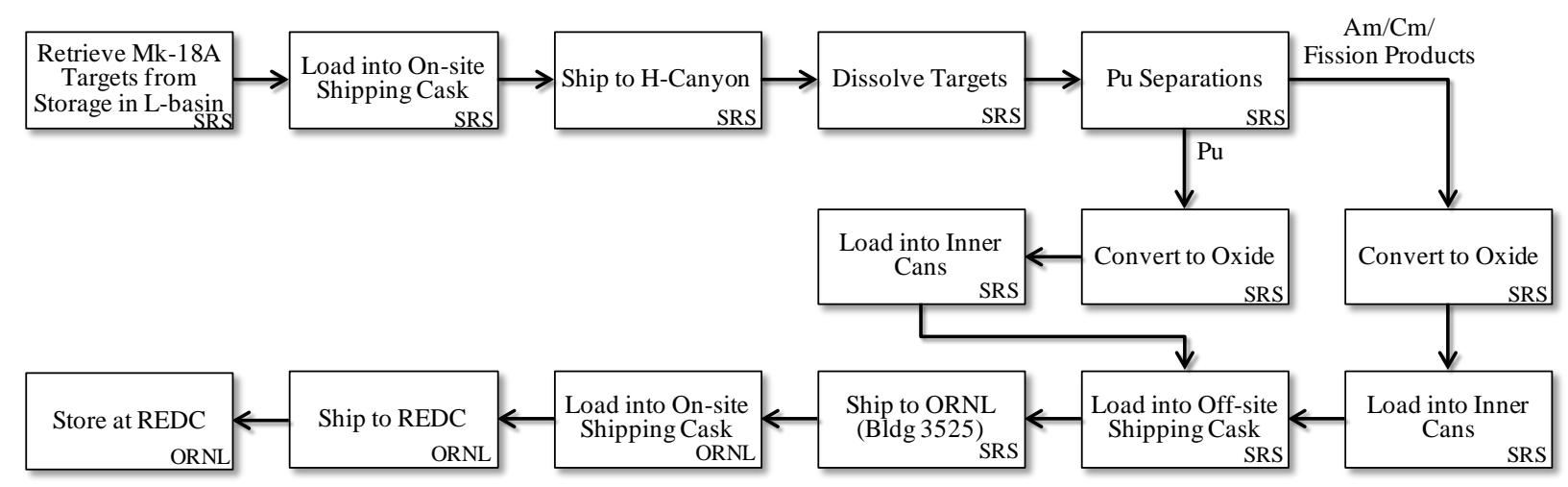

Fig. 5. Disposition of Mk-18A targets via dissolution and plutonium recovery and heavy-curium recovery at SRS (Pathway 3).

\subsection{DISPOSITION PATHWAY 4: DISSOLUTION AND ${ }^{244}$ Pu RECOVERY AT SRS AND CURIUM PROCESSING FOR DISPOSAL AS WASTE AT SRS}

Disposition Pathway 4 is similar to Pathways 3 except the Am/Cm/fission products stream is disposed of as waste rather than processed for the recovery of the heavy curium. The proposed process flow diagram is shown in Fig. 6.

The targets would be retrieved from their storage location in L-Basin at SRS and shipped to H-Canyon, where they would be dissolved and the plutonium separations step would be performed. The ${ }^{244} \mathrm{Pu}$ stream from the plutonium separations step would be converted to an oxide and packaged in containers that could be shipped to REDC for storage. The Am/Cm/fission products solution from the plutonium separations step would be transferred as waste to the SRS Tank Farm for solidification at the Defense Waste Processing Facility (DWPF). The solidified waste form would be stored at the SRS site until it could be loaded into off-site shipping casks and shipped to a geological repository for disposal.

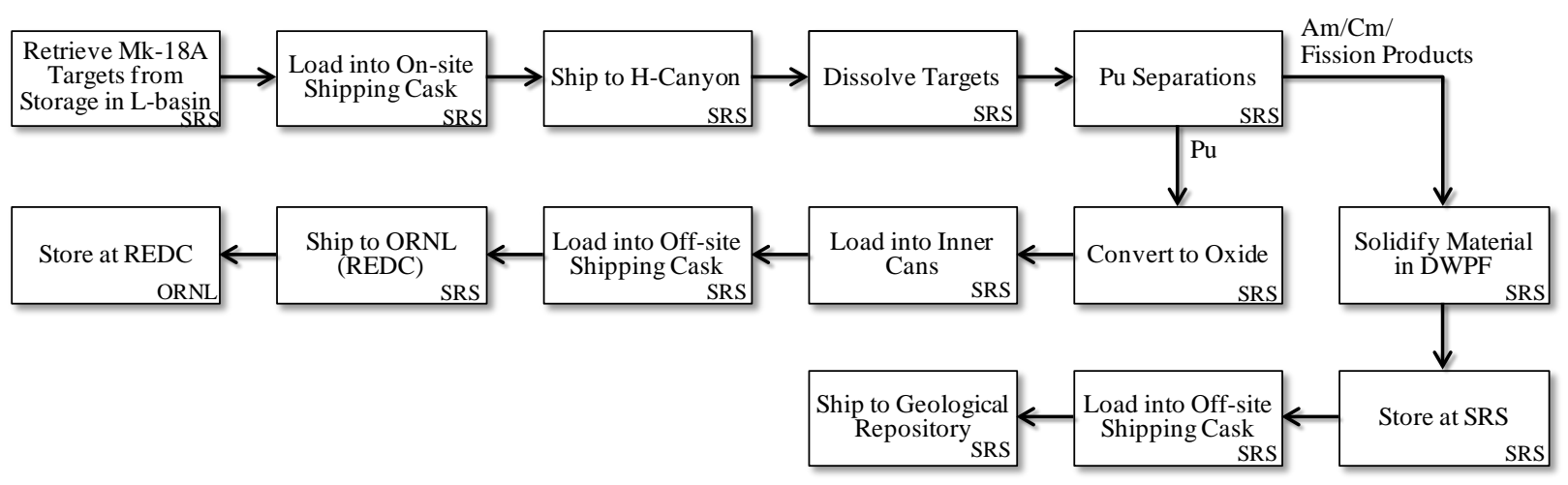

Fig. 6. Disposition of Mk-18A targets via dissolution, plutonium recovery, and curium processing for disposal as waste at SRS (Pathway 4).

\subsection{DISPOSITION PATHWAY 5: PROCESSING AT SRS FOR DISPOSAL AS WASTE}

The proposed flow diagram for the disposition of Mk-18A targets at a geological repository includes retrieval of the targets from storage in L-Basin, loading them into an on-site shipping cask, shipping them to $\mathrm{H}$-Canyon, dissolving the targets in $\mathrm{H}$-Canyon, and processing the materials at DWPF for solidification as waste, followed by interim storage at SRS until the material is ultimately shipped to a geological repository for disposal. The United States has suspended its program for high-level waste disposal at a 
geological repository, but SRS continues to stabilize its high-level waste in the DWPF for storage pending offsite disposal. Although the timing of this transfer cannot be guaranteed, the costs and environmental impacts of interim storage of the DWPF product and eventual disposal to a repository are well defined. The proposed process flow diagram for Disposition Pathway 5 is illustrated in Fig. 7.

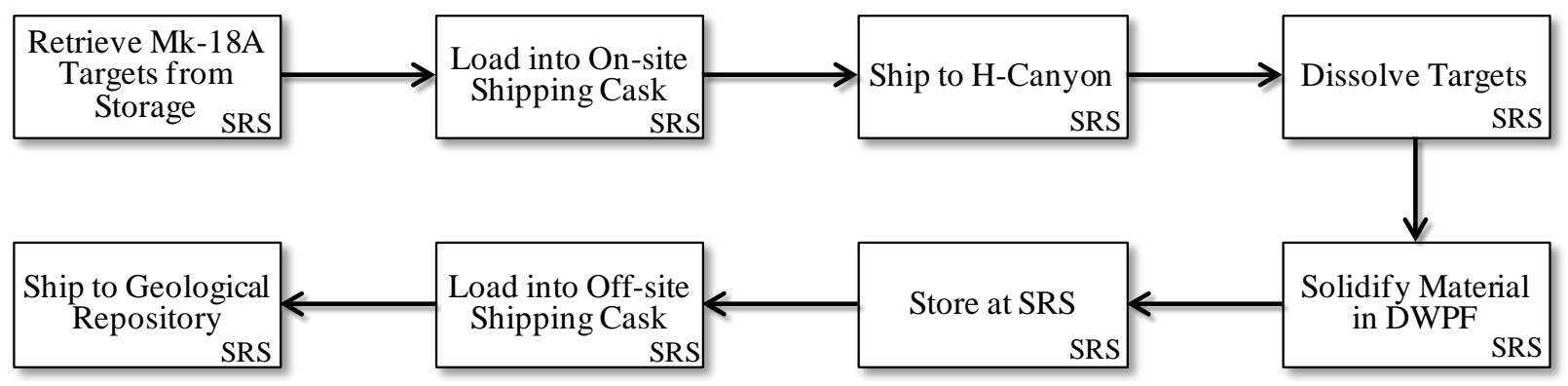

Fig. 7. Disposition of Mk-18A targets as waste at SRS (Pathway 5).

\section{EVALUATION METHODOLOGY}

An alternatives evaluation was performed to rank the disposition options for each target material using a decision-making methodology that provides a structured framework for comparing both qualitative and quantitative selection criteria. The selection criteria for disposition pathways for the target materials include the following.

- $\quad$ Technical feasibility - Considers likelihood of successful implementation based on processing requirements, shipping/staging requirements, regulatory approvals required, and acceptance by the DOE sites.

- Cost and schedule - Considers installation cost, operating cost, and impact on operating schedules at SRS and ORNL.

- Value of the material - Considers uniqueness of the material for future beneficial use for heavyisotope production and for R\&D and standards.

- Addition of capabilities - Considers how useful the capabilities implemented for Mk-18A processing could be for other projects at SRS.

The relative importance of each selection criterion was developed by the evaluation team (e.g., how does one weigh the importance of "cost" as a selection criterion relative to "value of the recovered material for future use"?). The selection criterion and subcriterion were weighted by importance: $\mathrm{H}$ - high, $\mathrm{M}-$ medium, and L - low. Three ratings were used to determine how well an option met a given criterion or subcriterion: G - Good, A - Average, and P - Poor. Definitions were developed for the ratings for each criterion and subcriterion. These are summarized in Appendix A.

Each disposition pathway was then given a "score" for each of the individual selection criterion, and weighted ratings are obtained for each criterion by combining the individual score and the weighting factor for that selection criterion. An overall score was assigned to each disposition pathway by combining each of the individual weighted ratings. The ratings were assigned by the team based on experience guided by criteria definitions. In some cases, actual data (e.g., cost estimates for implementing the pathway) were used to assign ratings, and in other cases, qualitative assessments (e.g., value of the recovered material for future use) were used to assign ratings based on the criterion definitions developed by the team. 


\section{EVALUATION OF ALTERNATIVES}

Each of the five potential disposition pathways were evaluated using the process described in the previous section of this report. The results are summarized in Table 4, and the information used to evaluate the processes is discussed below.

Table 4. Evaluation Results for Mk-18A Disposition Alternatives

\begin{tabular}{|c|c|c|c|c|c|c|c|c|c|c|}
\hline $\begin{array}{c}\text { Evaluation } \\
\text { Criteria }\end{array}$ & & $\begin{array}{l}\text { st/ } \\
\text { dule } \\
\text { 1) }\end{array}$ & Uni & $\begin{array}{l}\text { eness } \\
\text { d) }\end{array}$ & & $\begin{array}{l}\text { Feas } \\
\text { lem }\end{array}$ & $\begin{array}{l}\text { ility } \\
\text { tatio }\end{array}$ & & $\begin{array}{c}\text { Adding } \\
\text { Capabilities } \\
\text { (M) }\end{array}$ & $\begin{array}{l}\text { Overall } \\
\text { Rating }\end{array}$ \\
\hline Sub-criteria & $\begin{array}{l}\stackrel{+}{n} \\
\frac{U}{\pi} \\
\stackrel{0}{0} \\
\vdash\end{array}$ & $\begin{array}{l}\frac{0}{J} \\
\frac{0}{0} \\
\frac{d}{U} \\
\text { v }\end{array}$ & 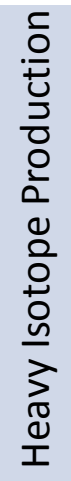 & 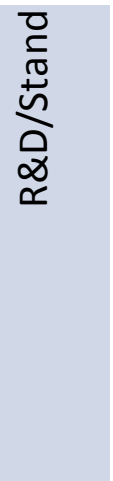 & 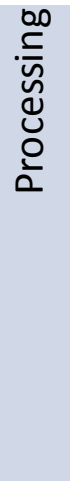 & 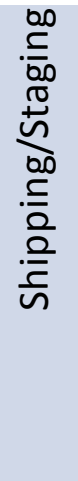 & 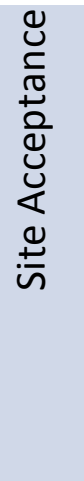 & $\begin{array}{l}\frac{7}{0} \\
0 \\
\frac{+}{0} \\
\frac{0}{3} \\
0 \\
0 \\
0 \\
0\end{array}$ & & \\
\hline $\begin{array}{l}\text { Weighting } \\
\text { Factor }\end{array}$ & $\mathrm{H}$ & $\mathrm{H}$ & $\mathrm{H}$ & $\mathrm{H}$ & $\mathrm{H}$ & $\mathrm{M}$ & $\mathrm{H}$ & M & M & - \\
\hline Pathway 1 & $\mathrm{P}$ & G- & $\mathrm{G}$ & G & $A$ & A & $A$ & $A$ & A & G- \\
\hline Pathway 2 & A & G & G & G & $A$ & A & $A+$ & $A$ & G & G \\
\hline Pathway 3 & A & $P$ & A & $A$ & $\mathrm{P}$ & A & $A$ & A & G & A \\
\hline Pathway 4 & A & $A$ & $P$ & $A$ & A & A & $A$ & A & G & $\mathbf{P +}$ \\
\hline Pathway 5 & G & $A$ & $\mathrm{P}$ & $P$ & G & G & $\mathrm{G}$ & G & $P$ & $\mathbf{P}$ \\
\hline
\end{tabular}

$\mathrm{H}=$ High, $\mathrm{M}=$ Medium, $\mathrm{L}=$ Low, $\mathrm{G}=$ Good, $\mathrm{A}=$ Average, $\mathrm{P}=$ Poor

\subsection{COST AND SCHEDULE}

Preliminary feasibility-level order-of-magnitude cost estimates were developed for each of the disposition pathways summarized in the Disposition Options section (Sect. 4) of this report (see Appendix B for detailed flowsheets used to develop the cost estimates). They include costs for the major steps for the disposition pathways including packaging/transport of the targets to treatment/storage facilities, dissolution of the targets, and processing of the material for one of two disposition endpoints: recovery of isotopes and/or disposal as waste. The cost estimates assume that DOE-EM will continue to fund the base costs for operating H-Canyon ( $\sim 150 \mathrm{M} / \mathrm{yr})$ through 2023 , and that only the incremental costs for processing Mk-18A targets will need to be covered by the project. The full allocated costs for processing/operating facilities at ORNL are assumed in these cost estimates.

The estimated costs for process modifications/startup and processing at each site are summarized in Table 5. The detailed cost estimates are given in Appendix C. All costs are in unescalated FY 2014 dollars. 
Table 5. Preliminary Cost Estimate for Mk-18A Disposition Pathways (\$M in 2014 dollars)

\begin{tabular}{|c|c|c|c|c|c|c|c|c|c|}
\hline \multirow[b]{3}{*}{ Pathway } & \multicolumn{6}{|c|}{ Safe Storage/Disposal } & \multicolumn{2}{|c|}{ Recovery } & \multirow[b]{3}{*}{$\begin{array}{l}\text { Grand } \\
\text { Total }\end{array}$} \\
\hline & \multicolumn{3}{|c|}{ SRS } & \multicolumn{5}{|c|}{ ORNL } & \\
\hline & $\begin{array}{c}\text { Process } \\
\text { Modification/ } \\
\text { Startup }\end{array}$ & $\begin{array}{l}\text { Repackaging/ } \\
\text { Recovery }\end{array}$ & Transport & $\begin{array}{c}\text { Process } \\
\text { Modification/ } \\
\text { Startup }\end{array}$ & $\begin{array}{c}\text { Resizing/ } \\
\text { Repackaging }\end{array}$ & $\begin{array}{c}\text { Safe } \\
\text { Storage } \\
\text { Total }\end{array}$ & Recovery & $\begin{array}{c}\text { Recovery } \\
\text { Total }\end{array}$ & \\
\hline $\begin{array}{l}1-\mathrm{Pu} / \mathrm{Am} / \mathrm{Cm} \\
\text { recovered at } \\
\text { ORNL }\end{array}$ & 17.8 & 20.9 & 5.3 & 0.3 & 10 & 54.3 & 26.5 & 26.5 & 80.7 \\
\hline $\begin{array}{l}2 \text { - Pu } / \mathrm{Am} / \mathrm{Cm} \\
\text { recovered at } \\
\text { SRS/ORNL }\end{array}$ & 24.1 & 22.0 & 2.7 & 0.2 & 5.5 & 54.4 & 15.9 & 15.9 & 70.3 \\
\hline $\begin{array}{l}3-\mathrm{Pu} / \mathrm{Am} / \mathrm{Cm} \\
\text { recovered at } \\
\text { SRS }\end{array}$ & 32.3 & 23.7 & 2.7 & 0.2 & 5.1 & 64.0 & 0 & 0 & 64.0 \\
\hline $\begin{array}{l}4-\mathrm{Pu} \\
\text { recovered at } \\
\text { SRS }\end{array}$ & 22.5 & 9.6 & 0.01 & 0 & 0.02 & 32.1 & 0 & 0 & 32.1 \\
\hline 5 - No recovery & 9.2 & 8.0 & 0 & 0 & 0 & 17.2 & 0 & 0 & 17.2 \\
\hline
\end{tabular}

Pathways 1-3 each have the same endpoints: the plutonium and Am/Cm materials are recovered and stored for future use at ORNL. The cost estimates indicate that there will be trade-offs for these options between the overall costs for recovering the materials, the near-term up-front costs required to upgrade/startup of processing facilities, the total costs for operations at SRS which must be completed by 2023 when H-Canyon is expected to shut down, and the processing costs at ORNL which can be completed over an extended period of time. For example, Pathway 3 has the lowest overall costs, but requires the largest up-front costs for getting the material into safe storage by 2023. The total cost for only recovering the plutonium (Pathway 4 ) is approximately half the cost of recovering both the plutonium and $\mathrm{Am} / \mathrm{Cm}$. Dispositioning all the material as waste (Pathway 5) has a substantially lower cost than recovering the materials for future use.

Two preliminary schedules were developed for each pathway. The first schedule (Fig. 8) looked at dispositioning the Mk-18A targets as fast as possible, and the second schedule (Fig. 9) was developed based on the need to produce materials at a rate to supply feedstock for the ${ }^{252} \mathrm{Cf}$ production program. The cost profiles associated with the two schedules are given in Tables 6 and 7, respectively.

The assumptions made to support the development of the processing schedules include the following.

- All SRS operations are completed by 2023 when H-Canyon is expected to shut down.

- $\quad$ SRS schedules assume Mk-18A processing occurs in parallel with other operations in H-Canyon through 2023. If H-Canyon shuts down earlier, some Mk-18A operations could be accelerated.

- $\quad$ To meet the ${ }^{252} \mathrm{Cf}$ production program need, a batch of recovered heavy curium is needed by 2019. Subsequent batches will be needed $\sim$ every 5 years thereafter.

- Plutonium-244 recovered on the ${ }^{252} \mathrm{Cf}$ demand schedule will be sufficient to meet programmatic and user needs. 


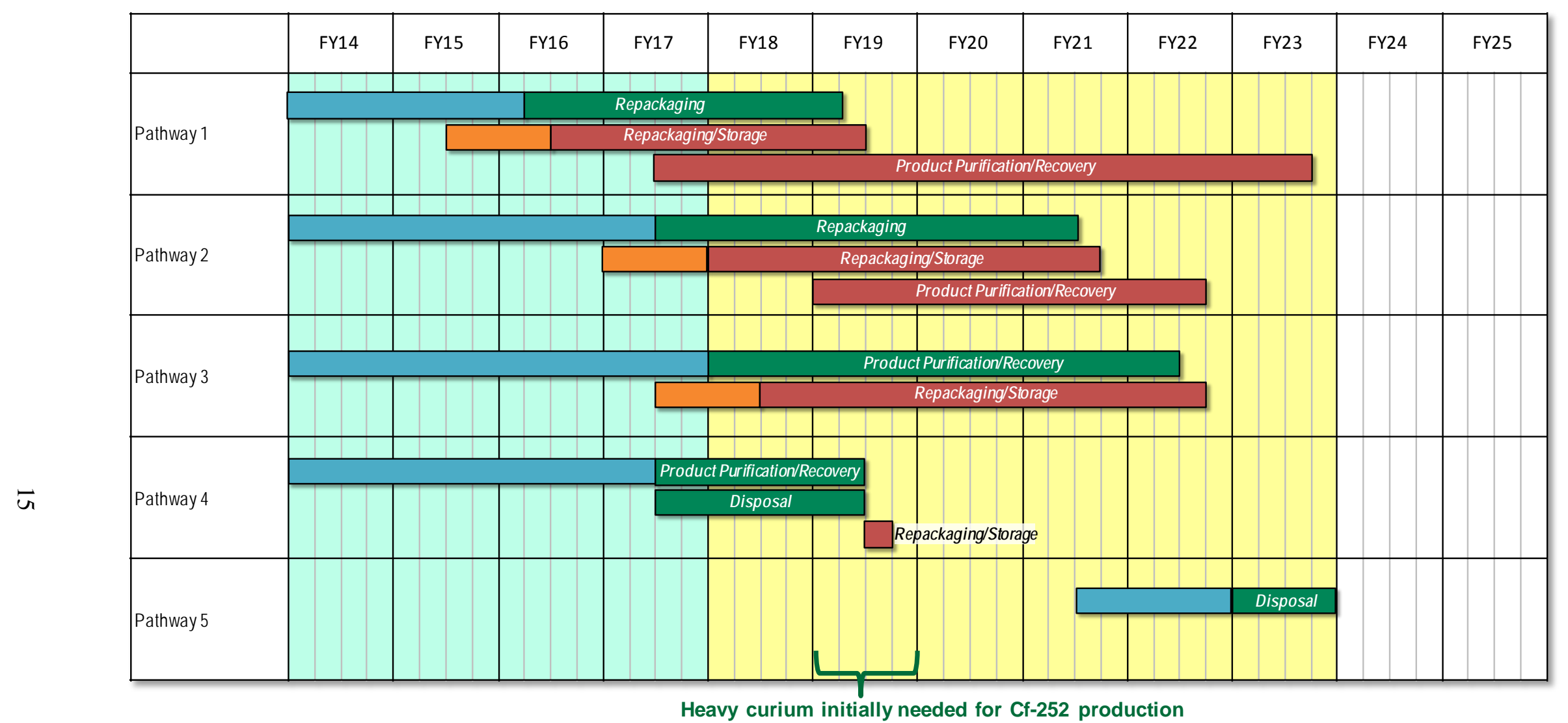

Heavy curium initially needed for Cf-252 production

SRS Process Modifications/Startup

SRS Operations

ORNL Process Modifications/Startup

ORNL Operations

DOE-EM Has Committed Funding for Base H-Canyon Operations Through 2017

$12 / 12 / 2012$

H-Canyon Has Inventory to Operate Through 2023

Fig. 8. Preliminary schedule for disposition of Mk-18A targets processing as fast as possible. 


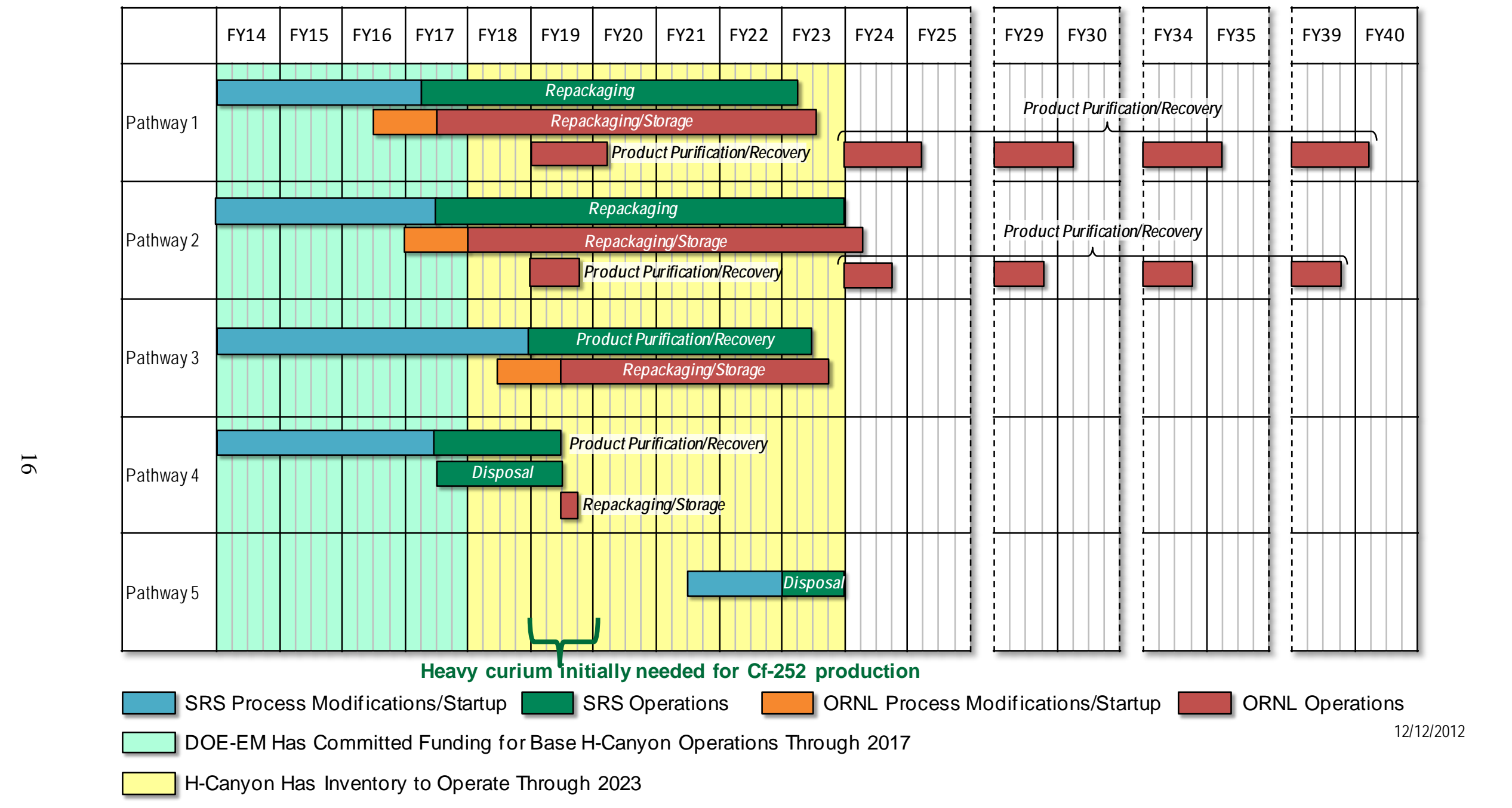

Fig. 9. Preliminary schedule for disposition of Mk-18A targets processing at a rate needed to support ${ }^{252} \mathrm{Cf}_{\text {production. }}$ 
Table 6. Preliminary Annual Cost Estimate (in 2014 Dollars) for Disposition of Mk-18A as Fast as Possible

\begin{tabular}{|c|c|c|c|c|c|c|c|c|c|c|c|c|c|c|c|c|c|c|c|c|c|c|c|c|c|c|c|c|}
\hline $\begin{array}{c}\text { Total } \\
\text { Project }\end{array}$ & FY14 & FY15 & FY16 & FY17 & FY18 & FY19 & FY20 & FY21 & FY22 & FY23 & FY24 & FY25 & FY26 & FY27 & FY28 & FY29 & FY30 & FY31 I & FY32 & FY33 & FY34 & FY35 & FY36 & FY37 & FY38 & FY39 & FY40 & Total \\
\hline Pathway 1 & 9.3 & 9.4 & 10.3 & 13.2 & 15.4 & 5.6 & 4.6 & 4.6 & 4.6 & 3.6 & - & - & - & - & - & - & - & - & - & - & - & - & - & - & - & - & - & 80 \\
\hline Pathway 2 & 7.3 & 7.3 & 7.3 & 7.1 & 6.9 & 11.2 & 11.2 & 8.1 & 3.6 & 0.4 & - & - & - & - & - & - & - & - & - & - & - & - & - & - & - & - & - & 70 \\
\hline Pathway 3 & 8.5 & 8.5 & 8.5 & 8.6 & 6.5 & 6.5 & 6.5 & 6.5 & 3.5 & 0.4 & - & - & - & - & - & - & - & - & - & - & - & - & - & - & - & - & - & 64 \\
\hline Pathway 4 & 6.4 & 6.4 & 6.4 & 5.6 & 4.8 & 2.4 & - & - & - & - & - & - & - & - & - & - & - & - & - & - & - & - & - & - & - & - & - & 32 \\
\hline Pathway 5 & - & - & - & - & - & - & - & 3.1 & 6.1 & 8.0 & - & - & - & - & - & - & - & - & - & - & - & - & - & - & - & - & - & 17 \\
\hline $\begin{array}{c}\text { Total } \\
\text { Project }\end{array}$ & FY14 & FY15 & FY16 & FY17 & FY18 & FY19 & FY20 & FY21 & FY22 & FY23 & FY24 & FY25 & FY26 & FY27 & FY28 & FY29 & FY30 & FY31 & FY32 & FY33 & FY34 & FY35 & FY36 & FY37 & FY38 & FY39 & FY40 & Total \\
\hline Pathway 1 & 4.2 & 8.5 & 6.4 & 5.4 & 5.8 & 10.0 & 6.8 & 5.8 & 5.8 & 0.9 & 4.2 & 1.1 & - & - & - & 4.2 & 1.1 & - & - & - & 4.2 & 1.1 & - & - & - & 4.2 & 1.1 & 80 \\
\hline Pathway 2 & 4.2 & 9.5 & 7.9 & 7.3 & 6.9 & 7.0 & 3.8 & 3.8 & 3.5 & 3.5 & 3.2 & - & - & - & - & 3.2 & - & - & - & - & 3.2 & - & - & - & - & 3.2 & - & 70 \\
\hline Pathway 3 & 4.2 & 9.1 & 7.4 & 6.9 & 7.0 & 6.5 & 6.5 & 6.5 & 6.5 & 3.5 & - & - & - & - & - & - & - & - & - & - & - & - & - & - & - & - & - & 64 \\
\hline Pathway 4 & 4.2 & 8.5 & 6.3 & 5.6 & 4.8 & 2.4 & - & - & - & - & - & - & - & - & - & - & - & - & - & - & - & - & - & - & - & - & - & 32 \\
\hline Pathway 5 & - & - & - & - & - & - & - & 3.1 & 6.1 & 8.0 & - & - & - & - & - & - & - & - & - & - & - & - & - & - & - & - & - & 17 \\
\hline
\end{tabular}


Evaluation of the schedules indicates that all options can be performed by 2023 when H-Canyon is expected to be shut down. However, Pathway 3 has the most schedule uncertainty and least slack time for implementation. It requires a large amount of up-front funding to implement process modifications. Funding delays would make this option, which has little slack time, nonviable (Fig. 8).

\subsection{UNIQUENESS OF THE MATERIAL FOR FUTURE REUSE}

The uniqueness of and need for the plutonium and heavy curium in the Mk-18A materials are discussed in the initial sections of the report. Pathways $1-3$ preserve the plutonium and heavy-curium materials for future use for ${ }^{252} \mathrm{Cf}$ production and isotopes R\&D/standards. The quality of the material recovered in Pathway 3 may be lower and processing losses higher compared to Pathways 1 and 2. Pathway 4 only preserves the plutonium, and Pathway 5 does not preserve the materials.

\subsection{FEASIBILITY OF IMPLEMENTATION}

Pathways 1 and 2 are considered to be the most technically feasible for providing the best quality material for future use because these isotopes separations are routinely performed at ORNL, and the capabilities to process the materials are in place at ORNL. New capabilities would need to be put in place at SRS to prepare the materials for shipment. Pathway 3 has the most technical uncertainty because SRS has not processed targets to recover these materials, and new processes would have to be installed to do so. Disposition of the material as waste has the least technical risk.

Shipping/staging, site acceptance, and regulatory issues were determined not to be discriminating evaluation criteria.

\subsection{ADDING CAPABILITIES TO THE SRS SITE}

Pathway 1 would require modifications to H-Canyon to provide an area for repackaging the Mk-18A targets prior to shipment to ORNL. These capabilities could potentially be useful for other future projects.

Pathways $2-4$ would require that a small dissolver (Dissolver 5.4) presently in standby be brought on line to process the Mk-18A targets for disposition. This dissolver would provide additional dissolver capacity to the two existing main line dissolvers in H-Canyon and could be used to process various materials in addition to the Mk-18A targets. Pathway 5 provides no additional capabilities.

\subsection{SUMMARY OF EVALUATED ALTERNATIVES AND RECOMMENDED PATHWAY}

Overall, Pathways 1 and 2 received "Good Minus” and "Good” ratings, respectively, while Pathways 3 5 received “Average” and "Poor” ratings. Pathways $1-3$ meet the DOE Strategic Plan objective of preserving the valuable and economically irreplaceable materials for future use. Pathway 3 received a lower overall rating because it requires the most near-term funding to get the material into safe storage, is the most technically risky, has the most schedule risk for not being implementable during the time frame $\mathrm{H}$-Canyon is expected to be operational, and has the highest potential for producing low-quality product for reuse. Pathway 2 is less costly than Pathway 1, has less technical uncertainty, and provides more capabilities at SRS to support other activities. It was, therefore, rated as the preferred pathway for recovery and storage of the Mk-18A targets. 


\section{SUMMARY AND CONCLUSIONS}

Even though the isotopes contained in the Mk-18A are very valuable, there are presently no direct programmatic sponsors for the Mk-18A materials within DOE. Therefore, DOE-EM has the option to disposition the targets as waste as part of their SRS cleanup mission. The Mk-18A targets need to be processed through the H-Canyon prior to its shutdown ( 2017 - 2023) to either recover the valuable isotopes to meet ${ }^{252} \mathrm{Cf}$ production needs or disposition the targets as waste. DOE-EM has committed to fund baseline operations of H-Canyon (\$150M/yr) through 2017, and SRS has an inventory of materials to be potentially processed through H-Canyon that could extend the life through 2023.

It is proposed that the targets be processed at the SRS H-Canyon prior to its shutdown, and the materials be sent to ORNL for safe storage and isotopes separations. To meet ${ }^{252} \mathrm{Cf}$ production needs, the target material could then be processed in approximately five batches at $\sim 5$ year intervals as needed for ${ }^{252} \mathrm{Cf}$ production starting in $\sim 2019$. The ${ }^{244} \mathrm{Pu}$-rich plutonium in the Mk-18A targets would be separated from the heavy curium and put in safe storage as part of this process.

Because of the long lead times to recover the Mk-18A material or to prepare targets and condition the available feed materials, efforts to preserve the economically irreplaceable ${ }^{244} \mathrm{Pu}$ and replenish the heavycurium feedstock must be initiated immediately to avoid ${ }^{252} \mathrm{Cf}$ supply interruptions. If no effort is made to recover the valuable heavy isotopes in these targets, then ${ }^{244} \mathrm{Pu}$ will not only be unavailable to meet recognized needs but also for any potential future uses in applied and basic sciences.

\section{REFERENCES}

J. M. Boswell, "Reactor Production Diversity," in 50 Years of Excellence in Science and Engineering at the Savannah River Site: Proceedings of the Symposium, WSRC-MS-2000-00061, May 17, 2000.

S. A. Goldberg et al., "Efforts to Save Pu-244 in Mark 18A Targets for Use in International Safeguards Measurements," IAEA-SM-367/5/01/P, 2001.

Ernest J. Moniz, "Savannah River Site Mark 18A Targets," Excess Material Disposition Decision Memorandum No. 3, January 28, 2001.

US Department of Energy, Strategic Plan, DOE/CF-0067, May 2011.

US DOE, Office of the Inspector General, Audit Report: Department of Energy's Management of Surplus Nuclear Materials, OAS-L-13-04, January 2013. 

APPENDIX A. EVALUATION CRITERIA DEFINITIONS 



\section{APPENDIX A. EVALUATION CRITERIA DEFINITIONS}

Table A.1. Weighting Factors for Evaluation Criteria

\begin{tabular}{|l|l|l|l|}
\hline \multicolumn{1}{|c|}{ Criteria } & $\begin{array}{c}\text { Weighting } \\
\text { Factor (H, M, L) }\end{array}$ & \multicolumn{1}{|c|}{ Subcriteria } & $\begin{array}{c}\text { Weighting } \\
\text { Factor (H, M, L) }\end{array}$ \\
\hline Feasibility of Implementation & M & Processing & M \\
\hline & Shipping/Staging & H \\
\hline Cost/Schedule & Acceptance at Site & M \\
\hline & Regulatory & H \\
\hline $\begin{array}{l}\text { Preserving Materials for } \\
\text { Future Use }\end{array}$ & Cost & Schedule & H \\
\hline & Uniqueness for Heavy-Isotope Production & H \\
\hline $\begin{array}{l}\text { Adding Capabilities to SRS } \\
\text { Site }\end{array}$ & M & Uniqueness for R\&D and Standards & H \\
\hline
\end{tabular}


Table A.2. Definitions for Rating Alternative Options

\begin{tabular}{|c|c|c|c|}
\hline Criteria/Subcriteria & Poor & Average & Good \\
\hline \multicolumn{4}{|l|}{ Feasibility of Implementation } \\
\hline Processing & $\begin{array}{l}\text { Requires major modifications to } \\
\text { existing facilities. Major } \\
\text { technical uncertainties in } \\
\text { processing flowsheet. }\end{array}$ & $\begin{array}{l}\text { Requires minor modifications } \\
\text { to existing facilities. Minor } \\
\text { technical uncertainties in } \\
\text { processing flowsheet. }\end{array}$ & $\begin{array}{l}\text { Uses existing processes/facilities. Uses } \\
\text { proven/routine processing flowsheet. }\end{array}$ \\
\hline Shipping /Staging & $\begin{array}{l}\text { Requires shipment between }>2 \\
\text { sites and/or in nonstandard } \\
\text { containers. Requires }>5 \text { years } \\
\text { storage prior to } \\
\text { shipment/disposition }\end{array}$ & $\begin{array}{l}\text { Requires shipment between } \\
2 \text { sites in standard } \\
\text { containers. Requires }<5 \\
\text { years storage prior to } \\
\text { shipment/disposition }\end{array}$ & $\begin{array}{l}\text { Handled at site where material resides } \\
\text { with little to no storage requirements }\end{array}$ \\
\hline Acceptance at site & $\begin{array}{l}\text { Requires multiple site/state } \\
\text { approvals }\end{array}$ & $\begin{array}{l}\text { Requires one site/state } \\
\text { approval other than where } \\
\text { material resides }\end{array}$ & Handled at site where material resides \\
\hline Regulatory & Multiple approvals & 1 approval & No approvals required \\
\hline \multicolumn{4}{|l|}{ Cost/Schedule } \\
\hline Cost & $>\$ 70 \mathrm{M}$ total costs & $\$ 20-70 \mathrm{M}$ total costs & $<\$ 20 M$ total costs \\
\hline Schedule & $\begin{array}{l}\text { Not consistent with facility } \\
\text { availability, product demand } \\
\text { schedule, and funding scenario }\end{array}$ & $\begin{array}{l}\text { Partly consistent with facility } \\
\text { availability, product demand } \\
\text { schedule, and funding } \\
\text { scenario }\end{array}$ & $\begin{array}{l}\text { Consistent with facility availability, } \\
\text { product demand schedule, and funding } \\
\text { scenario }\end{array}$ \\
\hline \multicolumn{4}{|c|}{ Preserving Materials for Future Use } \\
\hline $\begin{array}{l}\text { Uniqueness for Heavy } \\
\text { Element Production }\end{array}$ & Does not preserve $\mathrm{Cm}$ & $\begin{array}{l}\text { Preserves } \mathrm{Cm} \text { with material } \\
\text { quality uncertainties }\end{array}$ & $\begin{array}{l}\text { Preserves } \mathrm{Cm} \text { with known quality of } \\
\text { material }\end{array}$ \\
\hline $\begin{array}{l}\text { Uniqueness for R\&D } \\
\text { and Standards }\end{array}$ & Does not preserve $\mathrm{Pu}$ & $\begin{array}{l}\text { Preserves Pu with material } \\
\text { quality uncertainties }\end{array}$ & $\begin{array}{l}\text { Preserves Pu with known quality of } \\
\text { material }\end{array}$ \\
\hline \multicolumn{4}{|c|}{ Adding Capabilities to SRS Site } \\
\hline $\begin{array}{l}\text { Adds Capabilities to the } \\
\text { SRS Site }\end{array}$ & $\begin{array}{l}\text { Provides no capabilities to site } \\
\text { to perform additional projects }\end{array}$ & $\begin{array}{l}\text { Provides minor capabilities } \\
\text { to site to perform additional } \\
\text { projects }\end{array}$ & $\begin{array}{l}\text { Provides capabilities that are of interest } \\
\text { to implement other projects }\end{array}$ \\
\hline
\end{tabular}


APPENDIX B. DETAILED DESCRIPTIONS AND FLOWSHEETS FOR DISPOSITION PATHWAYS 



\title{
APPENDIX B. DETAILED DESCRIPTIONS AND FLOWSHEETS FOR DISPOSITION PATHWAYS
}

\author{
Disposition Pathway 1: Repackaging at SRS and Dissolution, ${ }^{244} \mathrm{Pu}$ Recovery, and Heavy-Curium \\ Recovery at ORNL
}

The SRS L-Area would load existing Mk-18A targets into an existing 70-ton cask and ship it to H-Canyon. Two targets per cask would be shipped, totaling 33 shipments to H-Canyon from L-Basin and 33 shipments from H-Canyon to ORNL. Modifications to H-Area would be made to receive the Mk-18A targets, remove them from existing J-cans/ tubes, and repackage and dry them for shipment to ORNL. A portable repacking basin tank with support features would be installed in the Hot Canyon Maintenance Shop. This repackaging tank would be equipped with personnel access and work platforms to allow personnel to work with extended tools similar to L-Basin. The tank and/or repackaging facility would be equipped with underwater can/tube cutting and handling equipment, tank-fill and pump-out capability, a shipping tube/can decontamination station, and support utilities and equipment. A National Lead Industries-Legal-Weight Truck (NLI-LWT) cask stand would be designed and fabricated to mount onto a railroad flat car to allow vertical loading of the NLI-LWT cask in the Hot Canyon Railroad Tunnel. A portable crane would be used to transport the LWT cask back and forth between its intermodal container and the cask loading railcar. Two targets would be shipped from SRS in a NLI-LWT shipping cask to ORNL's Irradiated Fuels Examination Laboratory (IFEL) in Bldg. 3525 where they would be cropped and sectioned into sizes (12 per target) that can be stored/processed (10 sections per shipment) in existing facilities at ORNL's REDC. The segments would then be shipped to REDC where they would be stored prior to being dissolved and the plutonium isotopes rich in ${ }^{244} \mathrm{Pu}$ separated from the $\mathrm{Am} / \mathrm{Cm} /$ fission products. The plutonium would be converted to an oxide, put into storage cans, and placed in storage at REDC for future enrichment of the ${ }^{244} \mathrm{Pu}$. The Am/Cm/fission products stream would be converted to an oxide, put into storage cans, and placed in storage at REDC for future use in targets for irradiation at the High Flux Isotope Reactor (HFIR). Based on operating experience at REDC, it is assumed that 15 dissolutions, 5 plutonium separations runs, 10 plutonium oxalate precipitation runs, and $50 \mathrm{Am} / \mathrm{Cm}$ oxalate precipitation runs would be required to process all the targets. See Fig. B.1.

\section{Disposition Pathway 2: Dissolution of Aluminum Cladding at SRS and ${ }^{244} \mathrm{Pu}$ and Heavy-Curium Recovery at ORNL}

The SRS L-Area would load existing Mk-18A targets into an existing 70-ton cask and ship it to $\mathrm{H}$-Canyon. Two targets per cask would be shipped, totaling 33 shipments to H-Canyon from L-Basin and 33 shipments from H-Canyon to ORNL. Modifications to H-Area would be made to receive Mk-18A targets, charge targets to the 5.4D Dissolver, perform caustic cladding (aluminum) removal, slurry and filter solids from dissolver basket/solution, filter/collect solids, transfer them to shipping cans, and dry them for shipment to ORNL. Modifications to the spare 5.4D dissolver would also be made to accommodate 14-ft-long target/J-cans, install the 5.4D dissolver and jumpers, return to service 5.4D support equipment/utilities, and install remotely operable 5.4D filter and slurry pumping system equipment. In addition, a solids transfer and drying system and shipping tube/can decontamination station and support utilities and equipment would need to be installed. A LWT cask stand would be designed and fabricated to mount onto a railroad flat car to allow vertical loading of the NLI-LWT cask in the Hot Canyon Railroad Tunnel. A portable crane would be used to transport the NLI-LWT cask back and forth between its intermodal container and the cask loading railcar. It is assumed that the $\mathrm{Pu} / \mathrm{Am} / \mathrm{Cm} / \mathrm{caustic}-$ insoluble fission product oxides would be dried, stabilized, and packaged into one transport container per target, and four containers would be shipped to ORNL in a NLI-LWT shipment. The packaged material would be unloaded from the off-site shipping container and transferred to an on-site shipping cask in ORNL's IFEL. The Mk-18A material would then be shipped to REDC, where it would be stored until it 
could be dissolved in nitric acid and the plutonium separated from the Am/Cm/fission products. The plutonium-bearing stream would be converted to an oxide, put into storage cans, and placed in storage at REDC for future enrichment. Based on operating experience at REDC, it is assumed that 15 dissolutions, 5 plutonium separations runs, 10 plutonium oxalate precipitation runs, and $50 \mathrm{Am} / \mathrm{Cm}$ oxalate precipitation runs would be required to process all the targets. See Fig. B.2.

\section{Disposition Pathway 3: Dissolution and ${ }^{244} \mathrm{Pu}$ and Heavy-Curium Recovery at SRS}

The SRS L-Area would load existing Mk-18A targets into an existing 70-ton cask and ship it to $\mathrm{H}$-Canyon. Two targets per cask would be shipped, totaling 33 shipments to H-Canyon from L-Basin and 33 shipments from H-Canyon to ORNL. Modifications to H-Area would be made to receive Mk-18A targets, charge targets to the 5.4D Dissolver, perform acidic dissolution, slurry and filter silica solids from the dissolver solution and discard, transfer the solution to Frame Waste Recovery (FWR), and process on an existing anion exchange column to collect and purify plutonium $\left({ }^{244} \mathrm{Pu}\right)$, collect plutonium on a burnable resin in FWR (16.1-2) sampler, calcine, package, and ship the plutonium to ORNL. A double sulfate (or similar) in-tank precipitation in a FWR tank would be performed. Next the solids (Am, Cm, La, rare earths) would be slurried and filtered, transferred to a shipping can, and dried for shipment to ORNL. Modifications to the spare 5.4D dissolver would be made to accommodate 14-ft-long target/J-cans, install 5.4D and jumpers, return to service 5.4D support equipment/utilities, and install a remotely operable 5.4D filter and slurry pumping system equipment. The existing FWR resin column (RC-16) would be repaired (torn screen) or replaced with an existing spare column and returned to service with support utilities and equipment. In addition, a solids transfer and drying system, shipping tube/can decontamination station, and support utilities and equipment would need to be installed. A NLI-LWT cask stand would be designed and fabricated to mount onto a railroad flat car to allow vertical loading of the NLI-LWT cask in the Hot Canyon Railroad Tunnel for shipment of Am, Cm, La, and rare earths. A portable crane would be used to transport the NLI-LWT cask back and forth between its intermodal container and the cask loading railcar. It is assumed that the oxide powders from four targets would be shipped to ORNL in each NLI-LWT shipment. The packaged material would be unloaded from the offsite shipping container and transferred to an on-site shipping cask in ORNL's IFEL. The Mk-18A material would then be shipped to REDC, where it would be stored for future use. See Fig. B.3.

\section{Disposition Pathway 4: Dissolution and ${ }^{244}$ Pu Recovery at SRS and Curium Processing for Disposal as Waste at SRS}

The SRS L-Area would load existing Mk-18A targets into an existing 70 ton cask and ship to H-Canyon. The assumption is to ship 6 targets per cask shipment, totaling 11 shipments to H-Canyon from L-Basin. $\mathrm{H}$-Area will make modifications to receive Mk-18A targets, charge targets to the 5.4D Dissolver, perform acidic dissolution, slurry and filter silica solids from dissolver solution and discard, transfer solution to Frame Waste Recovery (FWR) and process on existing anion exchange column to collect and purify plutonium $\left({ }^{244} \mathrm{Pu}\right)$, collect plutonium on burnable resin in FWR (16.1-2) sampler, calcine, package, and ship plutonium to ORNL. Am, Cm, La, rare earths will be neutralized and transferred to the SRS Tank Farm or the Defense Waste Processing Facility (DWPF) sludge batch. H-Canyon will make modifications to the spare 5.4D dissolver to accommodate $14 \mathrm{ft}$-long target/J-cans, install 5.4D and jumpers, return to service 5.4D support equipment/utilities, and install remotely operable 5.4D filter and slurry pumping system equipment. The existing FWR resin column (RC-16) will be repaired (torn screen) or replaced with existing spare column and returned to service with support utilities and equipment. The purified plutonium would be shipped in a single shipment to ORNL's REDC in a 9975 cask where it would be stored awaiting future enrichment. See Fig. B.4. 


\section{Disposition Pathway 5: Processing at SRS for Disposal as Waste}

The SRS L-Area would load existing Mk-18A targets into an existing 70-ton cask and ship to H-Canyon. Six targets per cask would be shipped, totaling 11 shipments to H-Canyon from L-Basin. Modifications to $\mathrm{H}$-Area would be made to receive MK-18A targets, charge targets to the 6.1D /6.4D dissolver, perform nitric acid dissolution, neutralize dissolver solution, and discard to the H-Tank Farm or DWPF sludge batch. See Fig. B.5. 


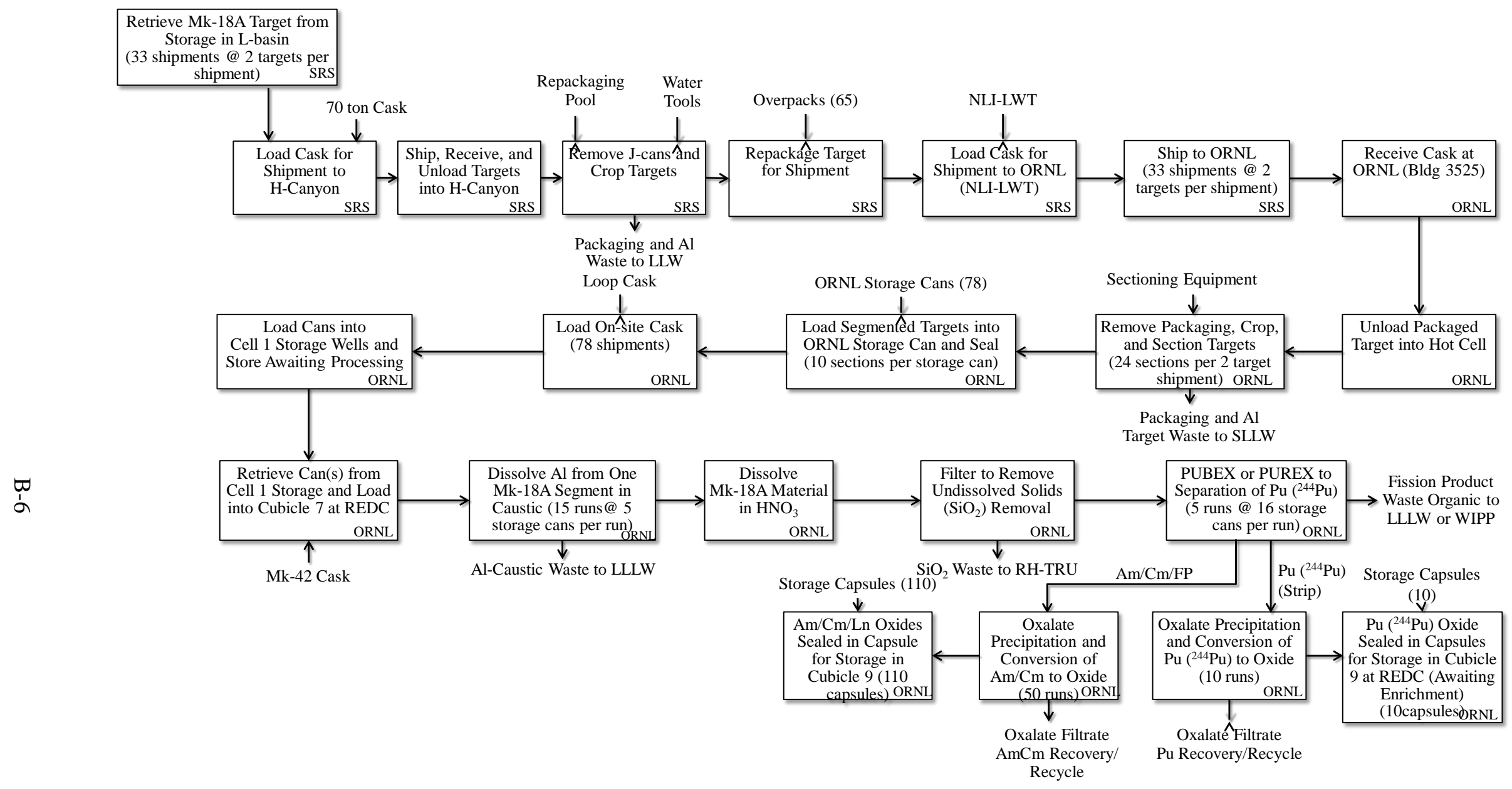

Fig. B.1. Disposition of Mk-18A targets via dissolution, plutonium recovery, and heavy-curium recovery at ORNL (Pathway 1). 


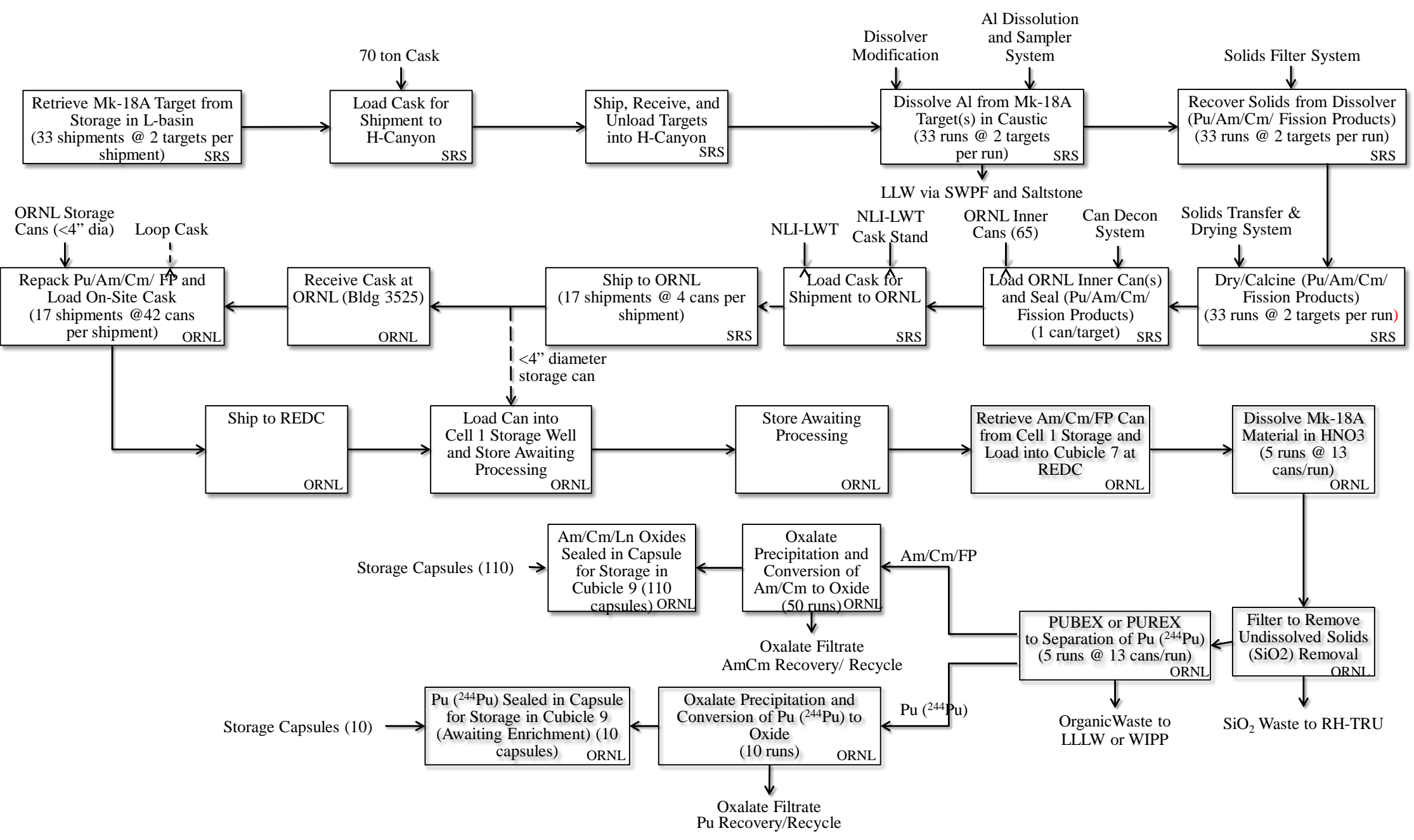

Fig. B.2. Disposition of Mk-18A targets via dissolution of aluminum cladding at SRS and plutonium and heavy-curium recovery at ORNL (Pathway 2). 


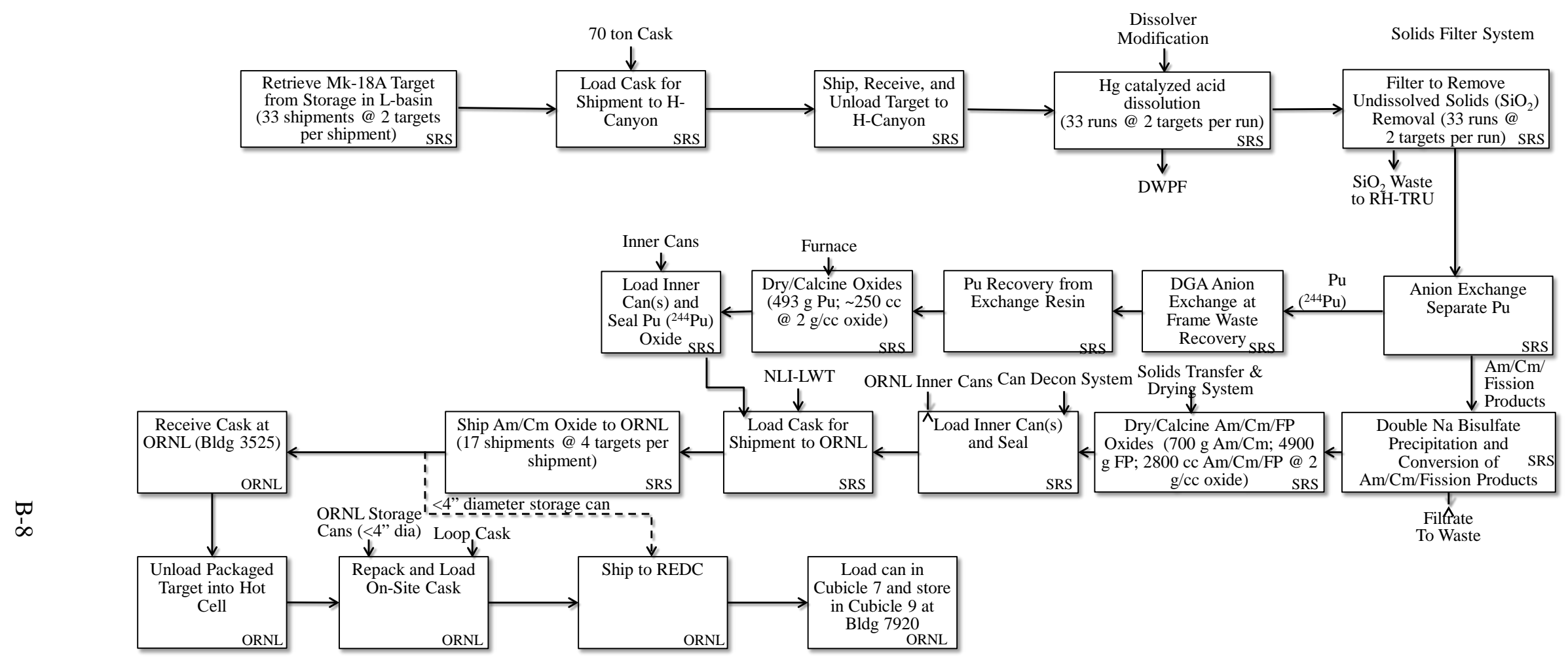

Fig. B.3. Disposition of Mk-18A targets via dissolution and plutonium recovery and heavy-curium recovery at SRS (Pathway 3). 


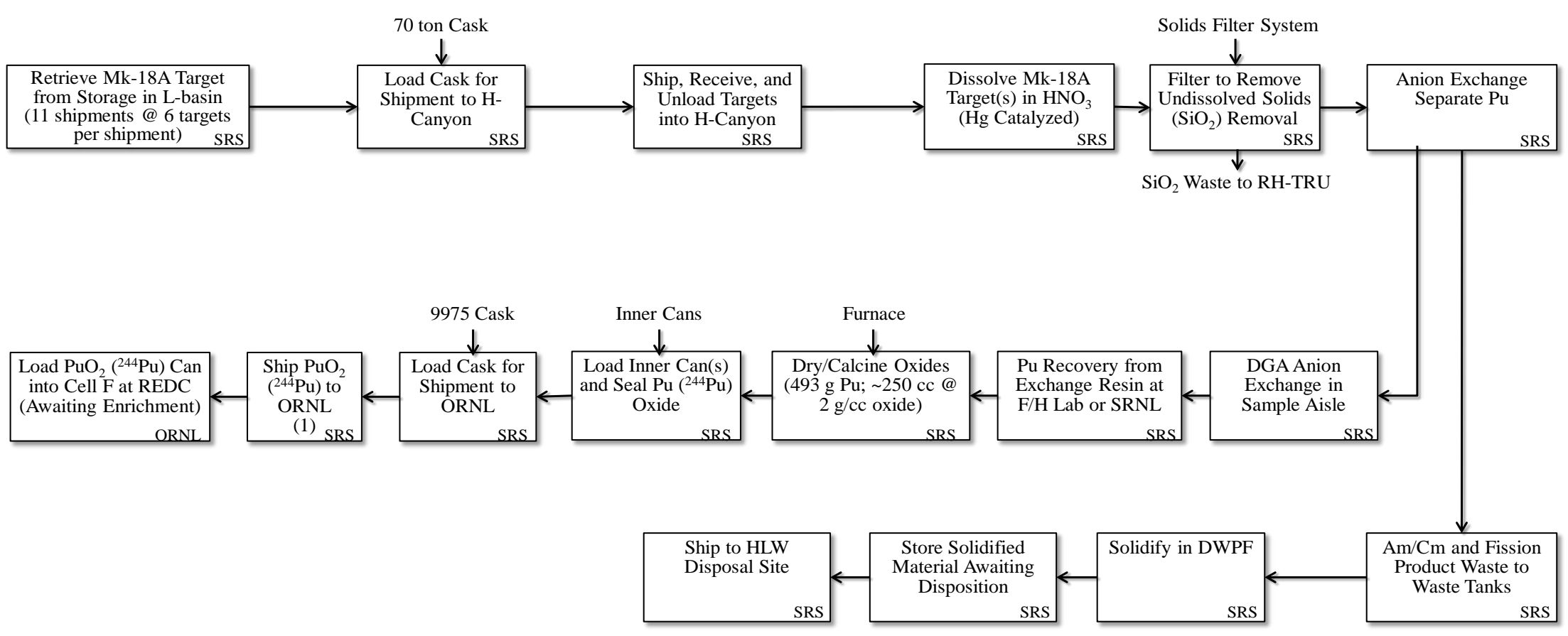

Fig. B.4. Disposition of Mk-18A targets via dissolution, plutonium recovery, and curium processing for disposal as waste at SRS (Pathway 4). 


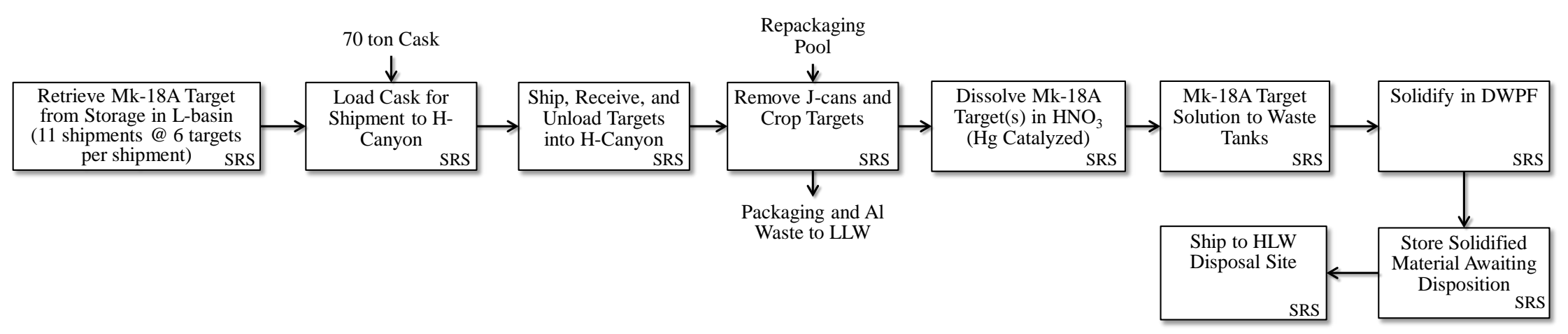

Fig. B.5. Disposition of Mk-18A targets as waste at SRS (Pathway 5). 


\section{APPENDIX C. DETAILED COST ESTIMATES}





\section{APPENDIX C. DETAILED COST ESTIMATES}

Table C.1. Costs for Disposition of Mk-18A Targets via Dissolution, Plutonium Recovery, and Heavy-Curium Recovery at ORNL (Pathway 1)

\begin{tabular}{|c|c|c|c|c|c|}
\hline Activities & Responsibility & $\begin{array}{l}\text { One-Time } \\
\text { Cost (\$K) }\end{array}$ & \begin{tabular}{|c|} 
Targets \\
Processed per \\
Activity \\
\end{tabular} & $\begin{array}{c}\text { Unit } \\
\operatorname{Cost}(\$ K)\end{array}$ & $\begin{array}{c}\text { Total } \\
\text { Reoccuring } \\
\text { Cost (\$K) } \\
\end{array}$ \\
\hline Retrieve Mk-18A target from storage in L-basin & SRS & & & & \\
\hline Prepare DSA/NCSE/OSA for 70-Ton transfers & SRS & 212 & & & \\
\hline Load 70-Ton Cask for Transfer & SRS & & 2 & 27 & 875 \\
\hline Transfer targets to repackaging location in H-Canyon & SRS & & & & \\
\hline Transfer targets & SRS & & 2 & 11 & 350 \\
\hline Unload targets into H-Canyon & SRS & & 2 & 214 & 7,058 \\
\hline H Canyon modifications & SRS & 15,759 & & & \\
\hline Repackage target for shipment & SRS & & & & \\
\hline Procure water tools & SRS & 267 & & & \\
\hline Obtain Overpacks (cans, tube) & SRS & & 1 & 5 & 345 \\
\hline Repackage target & SRS & & 1 & 107 & 6,951 \\
\hline Load cask for shipment to ORNL (NLI-LWT) & SRS & & & & \\
\hline Caks yoke/head bale/padeye & SRS & 535 & & & \\
\hline Crane rental & SRS & & 2 & 53 & 1,764 \\
\hline Load NLI-LWT & SRS & & 2 & 107 & 3,529 \\
\hline Ship to ORNL & SRS & 1,061 & 2 & 164 & 5,327 \\
\hline Prepare target for REDC processing at Blg 3525 & ORNL & 76 & 2 & 142 & 4,617 \\
\hline Waste disposal & ORNL & 107 & & & \\
\hline Load segmented targets into ORNL storage can and seal & ORNL & & & & \\
\hline Procure storage cans & ORNL & 11 & 1 & 6 & 498 \\
\hline Load on-site cask for transport to REDC & ORNL & 62 & & & \\
\hline Transfer to REDC for storage & ORNL & & 1 & 11 & 856 \\
\hline Perform separations & ORNL & & 13 & 5,305 & 26,523 \\
\hline Project Managemetnt & ORNL & & & & 4,000 \\
\hline Total & & 18,089 & & & 62,693 \\
\hline Grand Total & & & & & $\mathbf{8 0 , 7 8 2}$ \\
\hline
\end{tabular}


Table C.2. Costs for Disposition of Mk-18A Targets via Dissolution at SRS and Plutonium and Heavy-Curium Recovery at ORNL (Pathway 2)

\begin{tabular}{|c|c|c|c|c|c|}
\hline Activities & Responsibility & $\begin{array}{l}\text { One-Time } \\
\text { Cost (\$K) }\end{array}$ & $\begin{array}{c}\text { Targets } \\
\text { Processed per } \\
\text { Activity } \\
\end{array}$ & $\begin{array}{c}\text { Unit } \\
\text { Cost(\$K) }\end{array}$ & $\begin{array}{c}\text { Total } \\
\text { Reoccuring } \\
\text { Cost (\$K) } \\
\end{array}$ \\
\hline Retrieve Mk-18A target from storage in L-basin & SRS & & & & \\
\hline \begin{tabular}{|l} 
Prepare DSA/NCSE/OSA for 70-Ton transfers \\
\end{tabular} & SRS & 212 & & & \\
\hline Load 70-Ton Cask for Transfer & SRS & & 2 & 27 & 875 \\
\hline Transfer targets to repackaging location in H-Canyon & SRS & & & & \\
\hline \begin{tabular}{|c|} 
Transfer targets \\
\end{tabular} & SRS & & 2 & 11 & 350 \\
\hline Unload targets into H-Canyon & SRS & & 2 & 214 & 7,058 \\
\hline $\begin{array}{l}\text { H Canyon modifications to dissolve, recover, dry, and load material } \\
\text { for shipment in LWT }\end{array}$ & SRS & 22,257 & & & \\
\hline Dissolve and recover $\mathrm{Pu} / \mathrm{Am} / \mathrm{Cm} / \mathrm{FP}$ & SRS & & & & \\
\hline Perform dissolution/filtration operation & SRS & & 2 & 246 & 8,117 \\
\hline Dry and package material for shipment to ORNL & SRS & & & & \\
\hline Dry/Calcine $\mathrm{Pu} / \mathrm{Am} / \mathrm{Cm} / \mathrm{FP}$ & SRS & & 2 & 80 & 2,647 \\
\hline Obtain inner cans & SRS & & 2 & 5 & 172 \\
\hline Load cask for shipment to ORNL (NLI-LWT) & SRS & & & & \\
\hline \begin{tabular}{|l|} 
Caks yoke/head bale/padeye \\
\end{tabular} & SRS & 535 & & & \\
\hline Crane rental & SRS & & 4 & 53 & 909 \\
\hline Load NLI-LWT & SRS & & 4 & 107 & 1,818 \\
\hline Ship to ORNL Bldg 3525 & SRS & 1,061 & 4 & 164 & 2,664 \\
\hline Prepare Am/Cm oxide for REDC processing at Blg 3525 & ORNL & 76 & 2 & 23 & 762 \\
\hline Load oxide into ORNL storage can and seal & ORNL & 53 & & & \\
\hline Procure $<4$ " storage cans & ORNL & 11 & & & \\
\hline Load on-site cask for transport to REDC & ORNL & 62 & & & \\
\hline Transfer to REDC for storage & ORNL & & 1 & 11 & 710 \\
\hline Perform separations & ORNL & & 13 & 3,183 & 15,914 \\
\hline Project Managemetnt & ORNL & & & & 4,000 \\
\hline Total & & 24,266 & & & 45,995 \\
\hline Grand Total & & & & & 70,261 \\
\hline
\end{tabular}


Table C.3. Costs for Disposition of Mk-18A Targets via Dissolution and Plutonium Recovery and Heavy-Curium Recovery at SRS (Pathway 3)

\begin{tabular}{|c|c|c|c|c|c|}
\hline Activities & Responsibility & $\begin{array}{l}\text { One-Time } \\
\text { Cost (\$K) }\end{array}$ & $\begin{array}{c}\text { Targets } \\
\text { Processed } \\
\text { per Activity }\end{array}$ & $\begin{array}{c}\text { Unit } \\
\text { Cost(\$K) }\end{array}$ & $\begin{array}{c}\text { Total } \\
\text { Reoccuring } \\
\text { Cost }(\$ K)\end{array}$ \\
\hline Retrieve Mk-18A target from storage in L-basin & SRS & & & & \\
\hline Prepare DSA/NCSE/OSA for 70-Ton transfers & SRS & 212 & & & \\
\hline Load 70-Ton Cask for Transfer & SRS & & 2 & 27 & 875 \\
\hline Transfer targets to repackaging location in H-Canyon & SRS & & & & \\
\hline Transfer targets & SRS & & 2 & 11 & 350 \\
\hline Unload targets into H-Canyon & SRS & & 2 & 214 & 7,058 \\
\hline $\begin{array}{l}\text { H Canyon modifications to dissolve, recover, dry, and load material } \\
\text { for shipment to ORNL }\end{array}$ & SRS & 30,478 & & & \\
\hline Dissolve and recover $\mathrm{Pu} / \mathrm{Am} / \mathrm{Cm} / \mathrm{FP}$ & SRS & & & & \\
\hline Perform dissolution/filtration operation & SRS & & 2 & 246 & 8,117 \\
\hline Dry and package $\mathrm{Am} / \mathrm{Cm} / \mathrm{FP}$ material for shipment to ORNL & SRS & & & & \\
\hline Dry/Calcine Am/Cm/FP & SRS & & 2 & 80 & 2,647 \\
\hline Obtain inner cans & SRS & & 1 & 5 & 345 \\
\hline Load cask for shipment to ORNL (NLI-LWT) & SRS & & & & \\
\hline Caks yoke/head bale/padeye & SRS & 535 & & & \\
\hline Crane rental & SRS & & 4 & 53 & 909 \\
\hline Load NLI-LWT & SRS & & 4 & 107 & 1,818 \\
\hline Perform Pu Separations & SRS & & & & \\
\hline Separate Pu from Am/Cm/Fission Products & SRS & & 65 & 1,561 & 1,561 \\
\hline Dry/Calcine Pu Oxides & SRS & & 65 & 21 & 21 \\
\hline Prepare Pu oxides for shipment to ORNL & SRS & & & & \\
\hline Procure inner cans & SRS & & 65 & 5 & 5 \\
\hline Ship Pu Oxide to ORNL & SRS & & 65 & & - \\
\hline Ship Am/Cm/FP Oxide to ORNL & SRS & 1,061 & 4 & 164 & 2,664 \\
\hline Prepare Am/Cm/FP for REDC processing at Blg 3525 & ORNL & 76 & 2 & 23 & 762 \\
\hline Load inner cans into ORNL storage can ( $<4$ ' dia) and seal & ORNL & 53 & & & \\
\hline Procure storage cans ( $<4$ " dia) & ORNL & 11 & & & \\
\hline Load on-site cask for transport to REDC & ORNL & 62 & & & \\
\hline Transfer to REDC for storage & ORNL & & 2 & 11 & 355 \\
\hline Project Managemetnt & ORNL & & & & 4,000 \\
\hline Total & & 32,487 & & & 31,487 \\
\hline Grand Total & & & & & 63,974 \\
\hline
\end{tabular}


Table C.4. Costs for Disposition of Mk-18A Targets via Dissolution, Plutonium Recovery, and Curium Processing for Disposal as Waste at SRS (Pathway 4)

\begin{tabular}{|c|c|c|c|c|c|}
\hline Activities & Responsibility & $\begin{array}{l}\text { One-Time } \\
\text { Cost (\$K) }\end{array}$ & \begin{tabular}{|c|} 
Targets \\
Processed \\
per Activity \\
\end{tabular} & $\begin{array}{c}\text { Unit } \\
\text { Cost(\$K) }\end{array}$ & \begin{tabular}{|c|} 
Total \\
Reoccuring \\
Cost (\$K) \\
\end{tabular} \\
\hline Retrieve Mk-18A target from storage in L-basin & SRS & & & & \\
\hline Prepare DSA/NCSE/OSA for 70-Ton transfers & SRS & 212 & & & \\
\hline Load 70-Ton Cask for Transfer & SRS & & 6 & 27 & 292 \\
\hline Transfer targets to repackaging location in H-Canyon & SRS & & & & \\
\hline Transfer targets & SRS & & 6 & 11 & 117 \\
\hline Unload targets into H-Canyon & SRS & & 6 & 214 & 2,353 \\
\hline $\begin{array}{l}\text { H Canyon modifications to dissolve, recover, dry, and } \\
\text { load material for shipment to ORNL }\end{array}$ & SRS & 22,003 & & & \\
\hline Dissolve and recover $\mathrm{Pu} / \mathrm{Am} / \mathrm{Cm} / \mathrm{FP}$ & SRS & & & & \\
\hline Perform dissolution/filtration operation & SRS & & 65 & 4,181 & 4,181 \\
\hline Perform Pu Separations & SRS & & & & \\
\hline Separate Pu from Am/Cm/Fission Products & SRS & & 65 & 1,561 & 1,561 \\
\hline Dry/Calcine Pu Oxides & SRS & & 65 & 21 & 21 \\
\hline Prepare Pu oxides for shipment to ORNL & SRS & & & & \\
\hline Procure inner cans & SRS & & 65 & 5 & 5 \\
\hline Load Pu oxide into inner can and weld & SRS & & & & \\
\hline Obtain 9975 cask & SRS & 265 & & & \\
\hline Load 9975 cask & SRS & & 65 & 11 & 11 \\
\hline Ship Pu Oxide to ORNL & SRS & & 65 & & - \\
\hline Receive and Store Pu Oxide at REDC & ORNL & & 65 & 16 & 16 \\
\hline Unload inner cans from 9975 & ORNL & & & & \\
\hline Load inner cans into Cell F & ORNL & & & & \\
\hline Prepare Am/Cm/FP for disposal as HLW & SRS & & 4 & 3 & 42 \\
\hline Transfer Am/Cm/FP stream to waste tanks & SRS & & & & \\
\hline Solidify in DWPF & SRS & & 65 & 1,000 & 1,000 \\
\hline Total & & 22,480 & & & 9,599 \\
\hline Grand Total & & & & & 32,079 \\
\hline
\end{tabular}


Table C.5. Costs for Disposition of Mk-18A Targets as Waste at SRS (Pathway 5)

\begin{tabular}{|c|c|c|c|c|c|}
\hline Activities & Responsibility & $\begin{array}{l}\text { One-Time } \\
\text { Cost (\$K) }\end{array}$ & $\begin{array}{c}\text { Targets } \\
\text { Processed } \\
\text { per Activity }\end{array}$ & $\begin{array}{c}\text { Unit } \\
\text { Cost(\$K) }\end{array}$ & $\begin{array}{c}\text { Total } \\
\text { Reoccuring } \\
\text { Cost (\$K) }\end{array}$ \\
\hline Retrieve Mk-18A target from storage in L-basin & SRS & & & & \\
\hline Prepare DSA/NCSE/OSA for 70-Ton transfers & SRS & 212 & & & \\
\hline Load 70-Ton Cask for Transfer & SRS & & 6 & 27 & 292 \\
\hline Transfer targets to repackaging location in H-Canyon & SRS & & & & \\
\hline Transfer targets & SRS & & 6 & 11 & 117 \\
\hline Unload targets into H-Canyon & SRS & & 6 & 214 & 2,353 \\
\hline H Canyon modifications & SRS & 8,956 & & & \\
\hline Prepare Mk-18A target for disposal as HLW & SRS & & & & \\
\hline Dissolve target in $\mathrm{HNO}_{3}$ (Hg catalyzed) & SRS & & 6 & 380 & 4,181 \\
\hline Transfer stream to waste tanks & SRS & & 4 & 3 & 42 \\
\hline Solidify in DWPF & SRS & & 65 & 1,061 & 1,061 \\
\hline Total & & 9,168 & & & 8,046 \\
\hline Grand Total & & & & & 17,214 \\
\hline
\end{tabular}


